Supporting Information

\title{
Isolation and Computational Studies of a Series of Terphenyl Substituted Diplumbynes with Ligand Dependent Lead-Lead Multiple-Bonding Character.
}

Joshua D. Queen, Markus Bursch, Jakob Seibert, Leonard R. Maurer, Bobby D. Ellis, James C. Fettinger, Stefan Grimme, and Philip P. Power*

Table of Contents

Experimental details for $\left[\mathrm{Li}\left(\mathrm{Et}_{2} \mathrm{O}\right) \mathrm{Ar}^{\mathrm{Pr}^{i}}{ }^{\mathrm{i}}\right]$ and $\mathbf{1}$.

Table S1. Selected X-ray Crystallographic data for $\mathbf{2}-\mathbf{8}$.

Figure S1. ${ }^{1} \mathrm{H}$ NMR spectrum of $\left\{\mathrm{Pb}(\mu-\mathrm{Br}) \mathrm{Ar}^{\mathrm{Pr}^{i}}\right\}_{2}(2)$ in $\mathrm{C}_{6} \mathrm{D}_{6}$ at $25^{\circ} \mathrm{C}$.

Figure S2. ${ }^{13} \mathrm{C}\left\{{ }^{1} \mathrm{H}\right\}$ NMR spectrum of $\left\{\mathrm{Pb}(\mu-\mathrm{Br}) \mathrm{Ar}^{\mathrm{Pr}^{i}}{ }_{8}\right\}_{2}(2)$ in $\mathrm{C}_{6} \mathrm{D}_{6}$ at $25^{\circ} \mathrm{C}$.

Figure S3. ${ }^{1} \mathrm{H}$ NMR spectrum of $\left\{\mathrm{Pb}(\mu-\mathrm{Br}) \mathrm{Ar}^{\mathrm{Bu}_{6}^{t}}\right\}_{2}(3)$ in $\mathrm{C}_{6} \mathrm{D}_{6}$ at $25^{\circ} \mathrm{C}$.

Figure $\mathrm{S} 4 .{ }^{13} \mathrm{C}\left\{{ }^{1} \mathrm{H}\right\}$ NMR spectrum of $\left\{\mathrm{Pb}(\mu-\mathrm{Br}) \mathrm{Ar}^{\mathrm{Bu}_{6}^{t}}\right\}_{2}(3)$ in $\mathrm{C}_{6} \mathrm{D}_{6}$ at $25^{\circ} \mathrm{C}$.

Figure S5. ${ }^{1} \mathrm{H}$ NMR spectrum of $\left\{\mathrm{Pb}(\mu-\mathrm{Br})\left(4-\mathrm{SiMe}_{3}-\mathrm{Ar}^{\mathrm{Pr}^{i}}{ }_{4}\right)\right\}_{2}(4)$ in $\mathrm{C}_{6} \mathrm{D}_{6}$ at $25^{\circ} \mathrm{C}$.

Figure S6. ${ }^{13} \mathrm{C}\left\{{ }^{1} \mathrm{H}\right\}$ NMR spectrum of $\left\{\mathrm{Pb}(\mu-\mathrm{Br})\left(4-\mathrm{SiMe}_{3}-\mathrm{Ar}^{\mathrm{Pr}^{i}}{ }_{4}\right)\right\}_{2}(4)$ in $\mathrm{C}_{6} \mathrm{D}_{6}$ at $25^{\circ} \mathrm{C}$.

Figure S7. ${ }^{1} \mathrm{H}$ NMR spectrum of $\left(\mathrm{PbAr}^{\mathrm{Pr}^{i}}{ }^{i}\right)_{2}(\mathbf{5})$ in $\mathrm{C}_{6} \mathrm{D}_{6}$ at $25^{\circ} \mathrm{C}$

Figure S8. ${ }^{13} \mathrm{C}\left\{{ }^{1} \mathrm{H}\right\}$ NMR spectrum of $\left(\mathrm{PbAr}^{\mathrm{Pr}^{i}}\right)_{2}(\mathbf{5})$ in $\mathrm{C}_{6} \mathrm{D}_{6}$ at $25^{\circ} \mathrm{C}$

Figure S9. ${ }^{1} \mathrm{H}$ NMR spectrum of $\left(\mathrm{PbAr}^{\mathrm{Bu}_{6}^{t}}\right)_{2}(\mathbf{6})$ in $\mathrm{C}_{6} \mathrm{D}_{6}$ at $25^{\circ} \mathrm{C}$. $\mathrm{S} 12$

Figure S10. ${ }^{13} \mathrm{C}\left\{{ }^{1} \mathrm{H}\right\}$ NMR spectrum of $\left(\mathrm{PbAr}^{\mathrm{Bu}}{ }_{6}^{t}\right)_{2}(\mathbf{6})$ in $\mathrm{C}_{6} \mathrm{D}_{6}$ at $25^{\circ} \mathrm{C}$. $\mathrm{S} 13$

Figure S11. ${ }^{1} \mathrm{H}$ NMR spectrum of $\left(\operatorname{PbAr}^{\mathrm{Pr}^{i}}\right)_{2}(7, \#)+\mathrm{Ar}^{\mathrm{Pr}^{i}}{ }_{4} \mathrm{H}(*)$ in $\mathrm{C}_{6} \mathrm{D}_{6}$ at $25^{\circ} \mathrm{C}$. $\mathrm{S} 14$

Figure S12. ${ }^{13} \mathrm{C}\left\{{ }^{1} \mathrm{H}\right\} \mathrm{NMR}$ of $\left.\mathrm{PbAr}^{\mathrm{Pr}^{i}}\right)_{2}(7, \#)+\mathrm{Ar}^{\mathrm{Pr}}{ }_{4}^{i} \mathrm{H}(*)$ in $\mathrm{C}_{6} \mathrm{D}_{6}$ at $25^{\circ} \mathrm{C}$. $\mathrm{S} 15$

Figure S13. ${ }^{1} \mathrm{H}$ NMR spectrum of $\left\{\mathrm{Pb}\left(4-\mathrm{SiMe}_{3}-\mathrm{Ar}^{\mathrm{Pr}^{i}}\right)\right\}_{2}\left(8 \cdot \mathrm{Et}_{2} \mathrm{O}\right)$ in $\mathrm{C}_{6} \mathrm{D}_{6}$ at $25^{\circ} \mathrm{C}$. $\mathrm{S} 16$

Figure S14. ${ }^{13} \mathrm{C}\left\{{ }^{1} \mathrm{H}\right\}$ NMR spectrum of $\left\{\mathrm{Pb}\left(4-\mathrm{SiMe}_{3}-\mathrm{Ar}^{\mathrm{Pr}^{i}}\right)\right\}_{2}\left(\mathbf{8} \cdot \mathrm{Et}_{2} \mathrm{O}\right)$ in $\mathrm{C}_{6} \mathrm{D}_{6}$ at $25^{\circ} \mathrm{C}$. $\mathrm{S} 17$

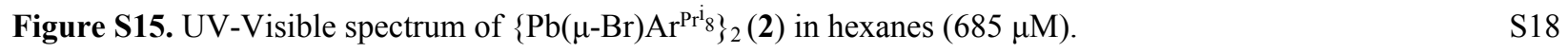

Figure S16. UV-Visible spectrum of $\left\{\mathrm{Pb}(\mu-\mathrm{Br}) \mathrm{Ar}^{\mathrm{Bu}_{6}^{\mathrm{t}}}\right\}_{2}(\mathbf{3})$ in hexanes $(101 \mu \mathrm{M})$. $\mathrm{S} 19$

Figure S17. UV-Visible spectrum of $\left\{\mathrm{Pb}(\mu-\mathrm{Br})\left(4-\mathrm{SiMe}_{3}-\mathrm{Ar}^{\mathrm{Pr}^{i}}{ }_{4}\right)\right\}_{2}(4)$ in hexanes $(921 \mu \mathrm{M}) . \quad \mathrm{S} 19$

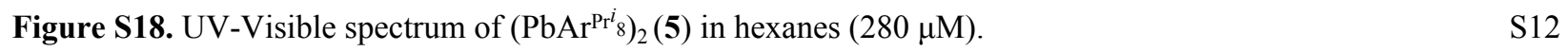

Figure S19. UV-Visible spectrum of $\left(\mathrm{PbAr}^{\mathrm{Pr}^{i}}\right)_{2}(\mathbf{5})$ in hexanes $(42.0 \mu \mathrm{M})$. $\mathrm{S} 20$

Figure S20. UV-Visible spectrum of $\left(\mathrm{PbAr}^{\mathrm{Bu}^{\mathrm{t}}}\right)_{2}(6)$ in hexanes $(596 \mu \mathrm{M}) \quad \mathrm{S} 21$

Figure S21. UV-Visible spectrum of $\left(\mathrm{PbAr}^{\mathrm{Bu}}{ }_{6}^{\mathrm{t}}\right)_{2}(6)$ in hexanes $(44.7 \mu \mathrm{M}) \quad \mathrm{S} 21$

Figure S22. UV-Visible spectrum of (7) in hexanes $(107 \mu \mathrm{M}) \quad$ S22

Figure S23. UV-Visible spectrum of $\mathbf{8} \cdot \mathrm{Et}_{2} \mathrm{O}$ in hexanes $(30.3 \mu \mathrm{M})$. $\quad \mathrm{S} 22$

Figure S24. Thermal ellipsoid plot of $\left\{\mathrm{Pb}(\mathrm{Br}) \mathrm{Ar}^{\mathrm{Pr}}{ }^{i}\right\}_{2}$ (2). $\mathrm{S} 23$

Figure S25. Thermal ellipsoid plot of $\left\{\mathrm{Pb}(\mu-\mathrm{Br}) \mathrm{Ar}^{\mathrm{Bu}_{6}^{\mathrm{t}}}\right\}_{2}(\mathbf{3})$.

Figure S26. Thermal ellipsoid plot of $\left\{\mathrm{Pb}(\mu-\mathrm{Br})\left(4-\mathrm{SiMe}_{3}-\mathrm{Ar}^{\mathrm{Pr}^{i}}{ }_{4}\right)\right\}_{2}(\mathbf{4})$. $\mathrm{S} 25$

Photos of compounds $\mathbf{5}-\mathbf{8} \quad S 26$

Computational details and tabulated data $\quad$ S28

Figure S27. MD averaged UV-Visible spectra for generated structures S29

Table S2. Structure scan data $\quad$ S30

Table S3. Energy contributions to $G_{\text {tot. }} \quad$ S34

Table S4. Dispersion energy contributions $\quad$ S36

$\begin{array}{ll}\text { References } & \text { S38 }\end{array}$ 


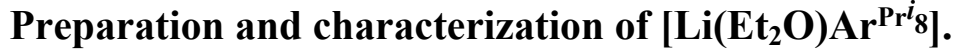

$\operatorname{Ar}^{\mathrm{Pr}^{\mathrm{i}} 8 \mathrm{I}^{\mathrm{S} 1}}(12.0 \mathrm{~g}, 17.3 \mathrm{mmol})$ was dissolved in a mixture of hexanes $($ ca. $80 \mathrm{~mL})$ and $\mathrm{Et}_{2} \mathrm{O}$ (ca. $\left.20 \mathrm{~mL}\right)$ and cooled to $0^{\circ} \mathrm{C}$ in an ice/water bath. $1.7 \mathrm{M}$ tert-BuLi in pentane $(20.8 \mathrm{~mL}, 35.5 \mathrm{mmol})$ was added dropwise over $10 \mathrm{~min}$. The mixture was allowed to come to ambient temperature and stirred for $12 \mathrm{~h}$. The volatile components were removed under reduced pressure and the solids extracted with hexane (ca. $60 \mathrm{~mL}$ ). The pale-yellow solution was concentrated to ca. $20 \mathrm{~mL}$ and stored at $-18^{\circ} \mathrm{C}$ overnight to give colorless crystals of the lithium salt. Yield: $9.3 \mathrm{~g}(83 \%) \mathrm{mp}=143-145^{\circ} \mathrm{C}$ (turns yellow with gas evolution) ${ }^{1} \mathrm{H}$ NMR (400 MHz, $\mathrm{C}_{6} \mathrm{D}_{6}, 298 \mathrm{~K}$ ): $\delta 7.32$ (s, 1H, ArH), 7.16 (s, 4H, ArH), 3.39 (sept, br, 4H, $\left.-\mathrm{CH}\left(\mathrm{CH}_{3}\right)_{2}\right), 2.87\left(\mathrm{~m}, 4 \mathrm{H},-\mathrm{CH}\left(\mathrm{CH}_{3}\right)_{2}\right), 2.66\left(\mathrm{q}, \mathrm{br}, 4 \mathrm{H}, \mathrm{O}\left(\mathrm{CH}_{2} \mathrm{CH}_{3}\right)_{2}\right), 1.36\left(\mathrm{~m}, 24 \mathrm{H},-\mathrm{CH}\left(\mathrm{CH}_{3}\right)_{2}\right), 1.29$ (d, $\left.12 \mathrm{H},-\mathrm{CH}\left(\mathrm{CH}_{3}\right)_{2}\right), 1.21\left(\mathrm{~d}, 12 \mathrm{H},-\mathrm{CH}\left(\mathrm{CH}_{3}\right)_{2}\right), 0.49$ (t, br, 6H, O $\left.\left(\mathrm{CH}_{2} \mathrm{CH}_{3}\right)_{2}\right) \cdot{ }^{13} \mathrm{C}\left\{{ }^{1} \mathrm{H}\right\} \mathrm{NMR}(101$ $\left.\mathrm{MHz}, \mathrm{C}_{6} \mathrm{D}_{6}, 289 \mathrm{~K}\right): \delta$ 147.5, 146.2, 145.5, 144.7, 141.2, 121.0, 120.7, 117.2, 65.8, 34.7, 32.0, 31.0, $30.0,26.2,25.5,24.5,24.4,23.1,14.4,14.1 .{ }^{7} \mathrm{Li}\left\{{ }^{1} \mathrm{H}\right\}\left(155 \mathrm{MHz}, \mathrm{C}_{6} \mathrm{D}_{6}, 289 \mathrm{~K}\right): \delta 0.95$.

\section{Synthesis of $\mathrm{Ar}^{\mathrm{Pr}^{i}} \mathrm{PbPbAr}^{\mathrm{Pr}^{i}}{ }_{6}(1)$.}

A solution of $\left\{\mathrm{Pb}(\mu-\mathrm{Br}) \mathrm{Ar}^{\mathrm{Pr}^{\mathrm{i}}} 6\right\}_{2}{ }^{\mathrm{S} 2}(1.00 \mathrm{~g}, 0.650 \mathrm{mmol})$ in $\mathrm{Et}_{2} \mathrm{O}(\mathrm{ca} .20 \mathrm{~mL})$ was cooled to $0^{\circ} \mathrm{C}$ in an ice/water bath. A solution of $\left(\mathrm{Mg}^{\mathrm{Mes} N a c n a c}\right)_{2}(0.468 \mathrm{~g} 0.650 \mathrm{mmol})$ in $\mathrm{Et}_{2} \mathrm{O}(\mathrm{ca} .5 \mathrm{~mL})$ was added dropwise over $2 \mathrm{~min}$, resulting in an immediate color change from yellow to dark brown. The solution stirred for $30 \mathrm{~min}$ and the volatile components were removed under reduced pressure. The dark residue was extracted with hexanes (ca. $30 \mathrm{~mL}$ ) and stored at $-30^{\circ} \mathrm{C}$ for 2 days to give large brown blocks of $\mathbf{1} \cdot$ hexane $(0.608 \mathrm{~g}, 0.415 \mathrm{mmol}, 64 \%)$, identified by the ${ }^{1} \mathrm{H}$ NMR spectrum in $\mathrm{C}_{6} \mathrm{D}_{6}$. 
Table S1. Selected X-ray Crystallographic data for $\mathbf{2}-\mathbf{8}$.

\begin{tabular}{|c|c|c|c|c|c|c|c|}
\hline Compound & 2 & $3+[$ solvent $]$ & 4 & $5 \cdot 1.5 \mathrm{C}_{7} \mathrm{H}_{8}$ & 6 & 7 & $8 \cdot \mathbf{E t}_{2} \mathrm{O}$ \\
\hline Formula & $\mathrm{C}_{84} \mathrm{H}_{122} \mathrm{Br}_{2} \mathrm{~Pb}_{2}$ & $\mathrm{C}_{84} \mathrm{H}_{122} \mathrm{Br}_{2} \mathrm{~Pb}_{2}$ & $\mathrm{C}_{66} \mathrm{H}_{90} \mathrm{Br}_{2} \mathrm{Si}_{2} \mathrm{~Pb}_{2}$ & $\mathrm{C}_{189} \mathrm{H}_{268} \mathrm{~Pb}_{4}$ & $\mathrm{C}_{84} \mathrm{H}_{122} \mathrm{~Pb}_{2}$ & $\mathrm{C}_{60} \mathrm{H}_{74} \mathrm{~Pb}_{2}$ & $\mathrm{C}_{70} \mathrm{H}_{100} \mathrm{Si}_{2} \mathrm{~Pb}_{2}$ \\
\hline Formula & 1706.02 & 1706.02 & 1513.76 & 3368.83 & 1546.19 & 1209.57 & 1428.05 \\
\hline \multicolumn{8}{|l|}{$\begin{array}{l}\text { Weight (g mol- } \\
\text { 1) }\end{array}$} \\
\hline $\mathbf{T}(\mathbf{K}) / \lambda(\AA)$ & $90(2) / 0.71073$ & $90(2) / 0.71073$ & $90(2) / 0.71073$ & $90(2) / 0.71073$ & $90(2) / 0.71073$ & $90(2) / 0.71073$ & $90(2) / 0.71073$ \\
\hline Crystal System & Monoclinic & Monoclinic & Triclinic & Monoclinic & Monoclinic & Triclinic & Monoclinic \\
\hline Space Group & $\mathrm{P} 2{ }_{1} / \mathrm{n}$ & $\mathrm{C} 2 / \mathrm{c}$ & P-1 & $\mathrm{P} 2{ }_{1} / \mathrm{n}$ & $\mathrm{C} 2 / \mathrm{c}$ & P-1 & $\mathrm{P} 2_{1} / \mathrm{c}$ \\
\hline $\mathbf{Z}$ & 4 & 4 & 1 & 2 & 8 & 1 & 2 \\
\hline $\begin{array}{l}\text { Crystal color } \\
\text { and habit }\end{array}$ & Yellow block & Yellow block & Yellow plate & $\begin{array}{c}\text { Red } \\
\text { parallelepiped }\end{array}$ & Green block & Amber block & $\begin{array}{l}\text { Amber/green } \\
\text { block }\end{array}$ \\
\hline $\mathbf{a}(\AA)$ & $14.946(2)$ & $14.6489(14)$ & $11.3682(9)$ & $18.3288(13)$ & $20.3372(17)$ & $9.1688(8)$ & $11.4812(12)$ \\
\hline b $(\AA)$ & $19.052(3)$ & $26.975(3)$ & $12.7595(10)$ & $23.6315(17)$ & $18.4518(14)$ & $12.7083(11)$ & $25.639(3)$ \\
\hline c (Å) & $28.498(4)$ & $22.733(2)$ & $12.9493(10)$ & $20.2841(15)$ & $38.674(3)$ & $13.0164(12)$ & $12.8116(14)$ \\
\hline$\alpha\left({ }^{\circ}\right)$ & 90 & 90 & $94.5630(12)$ & 90 & 90 & $64.2950(10)$ & 90 \\
\hline$\beta\left({ }^{\circ}\right)$ & $98.929(2)$ & $105.4841(13)$ & $103.1496(10)$ & $104.2710(10)$ & $90.3948(15)$ & 81.6790() 10 & $114.5876(13)$ \\
\hline$\gamma\left({ }^{\circ}\right)$ & 90 & 90 & $114.1017(10)$ & 90 & 90 & $69.5720(10)$ & 90 \\
\hline $\mathbf{V}\left(\AA^{3}\right)$ & $8016(2)$ & $8656.9(14)$ & $1637.9(2)$ & $8514.7(11)$ & $14512(2)$ & $1280.6(2)$ & $3429.4(6)$ \\
\hline$\rho\left(\mathrm{mg} \mathrm{mm}^{-3}\right)$ & 1.414 & 1.309 & 1.535 & 1.314 & 1.415 & 1.568 & 1.383 \\
\hline $\begin{array}{l}\text { Abs. coeff } \\
\left(\mathrm{mm}^{-1}\right)\end{array}$ & 5.231 & 4.844 & 6.425 & 3.992 & 4.677 & 6.601 & 4.976 \\
\hline $\mathbf{F}(000)$ & 3440 & 3440 & 748 & 3460 & 6320 & 598 & 1440 \\
\hline $\begin{array}{l}\text { Crystal size } \\
(\mathrm{mm})\end{array}$ & $\begin{array}{c}0.361 \times 0.331 \times \\
0.248\end{array}$ & $\begin{array}{c}0.194 \times 0.099 \times \\
0.092\end{array}$ & $\begin{array}{c}0.520 \times 0.312 \times \\
0.078\end{array}$ & $\begin{array}{c}0.252 \times 0.125 \times \\
0.068\end{array}$ & $\begin{array}{c}0.086 \times 0.068 \times \\
0.053\end{array}$ & $\begin{array}{c}0.160 \times 0.158 \times \\
0.141\end{array}$ & $\begin{array}{c}0.538 \times 0.438 \times \\
0.216\end{array}$ \\
\hline$\theta$ range $\left(^{\circ}\right)$ & 1.799 to 30.615 & 1.628 to 30.598 & 1.782 to 27.485 & 1.595 to 30.000 & 1.490 to 25.250 & 1.736 to 30.510 & 1.920 to 27.570 \\
\hline $\begin{array}{l}\text { Reflns } \\
\text { collected }\end{array}$ & 93991 & 49125 & 7514 & 96170 & 44040 & 7751 & 29678 \\
\hline Ind. Reflns. & 24555 & 13272 & 7514 & 24841 & 13165 & 7751 & 7912 \\
\hline R(int) & 0.0290 & 0.0880 & - & 0.0419 & 0.0956 & - & 0.0201 \\
\hline $\begin{array}{l}\text { Obs. reflns } \\
(I>2 \sigma(I))\end{array}$ & 21212 & 9197 & 7230 & 18353 & 9320 & 7178 & 7496 \\
\hline $\begin{array}{l}\text { Completeness } \\
\text { to } 2 \theta=25.242^{\circ}\end{array}$ & $99.9 \%$ & $99.9 \%$ & $99.9 \%$ & $100.0 \%$ & $100.0 \%$ & $100.0 \%$ & $100.0 \%$ \\
\hline $\begin{array}{l}\text { Goodness-of- } \\
\text { fit on } F^{2}\end{array}$ & 1.055 & 0.986 & 1.051 & 1.005 & 0.975 & 1.081 & 1.034 \\
\hline \multirow{2}{*}{$\begin{array}{l}\text { Final R } \\
(I>2 \sigma(I))\end{array}$} & $\mathrm{R} 1=0.0216$ & $\mathrm{R} 1=0.0372$ & $\mathrm{R} 1=0.0402$ & $\mathrm{R} 1=0.0283$ & $\mathrm{R} 1=0.0420$ & $\mathrm{R} 1=0.0232$ & $\mathrm{R} 1=0.0162$ \\
\hline & $w R 2=0.0441$ & $w R 2=0.0788$ & $w R 2=0.1091$ & $w R 2=0.0576$ & $w R 2=0.0783$ & $w R 2=0.0597$ & $w R 2=0.0408$ \\
\hline \multirow[t]{2}{*}{ R (all data) } & $\mathrm{R} 1=0.0287$ & $\mathrm{R} 1=0.0658$ & $\mathrm{R} 1=0.0416$ & $\mathrm{R} 1=0.0489$ & $\mathrm{R} 1=0.0734$ & $\mathrm{R} 1=0.0268$ & $\mathrm{R} 1=0.0174$ \\
\hline & $w R 2=0.0456$ & $w R 2=0.0882$ & $w R 2=0.1100$ & $w R 2=0.0644$ & $w R 2=0.0863$ & $w R 2=0.0611$ & $w R 2=0.0413$ \\
\hline
\end{tabular}




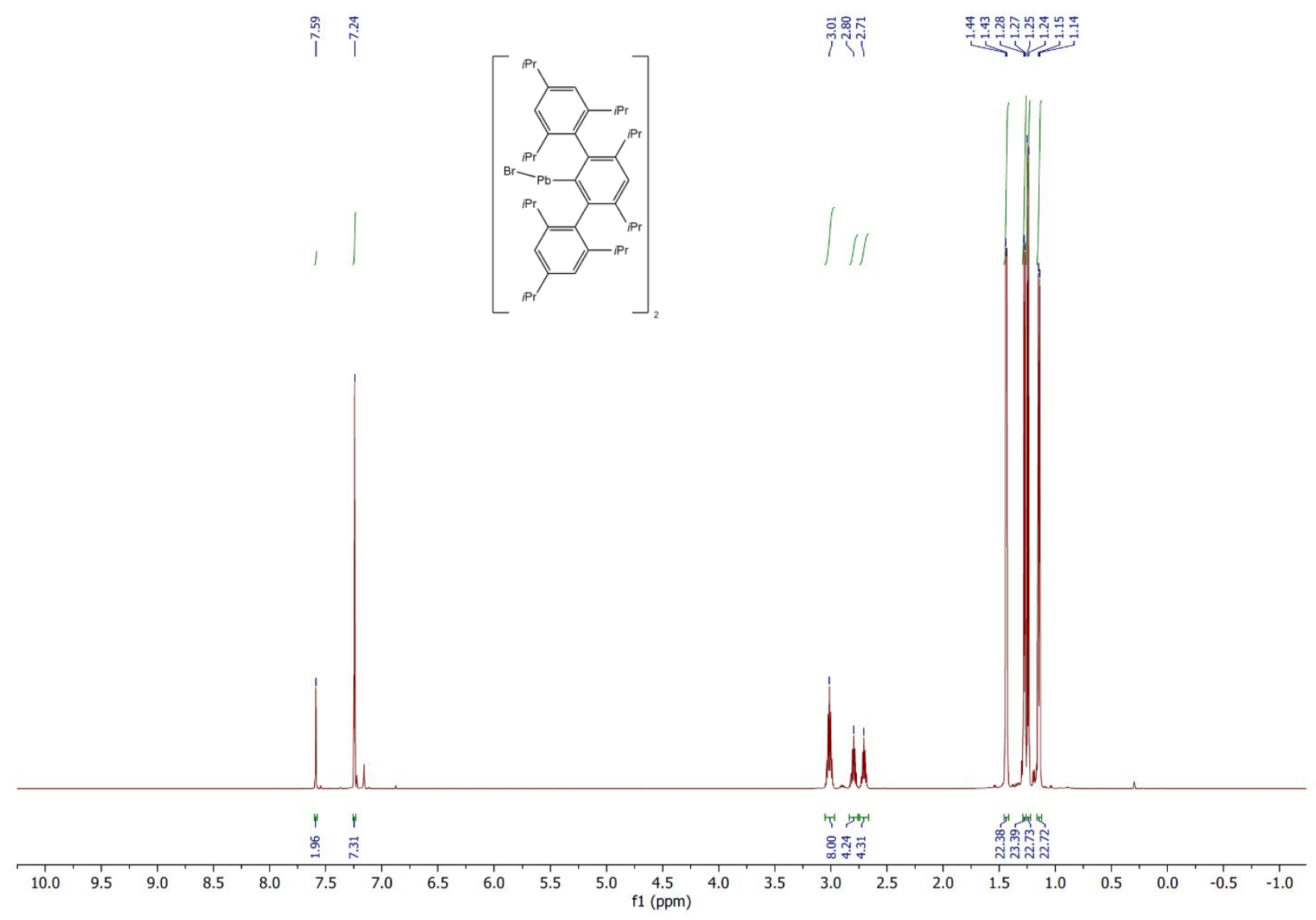

Figure S1. ${ }^{1} \mathrm{H}$ NMR spectrum of $\left\{\mathrm{Pb}(\mu-\mathrm{Br}) \mathrm{Ar}^{\mathrm{Pr}^{i}}\right\}_{2}(2)$ in $\mathrm{C}_{6} \mathrm{D}_{6}$ at $25^{\circ} \mathrm{C}$. 


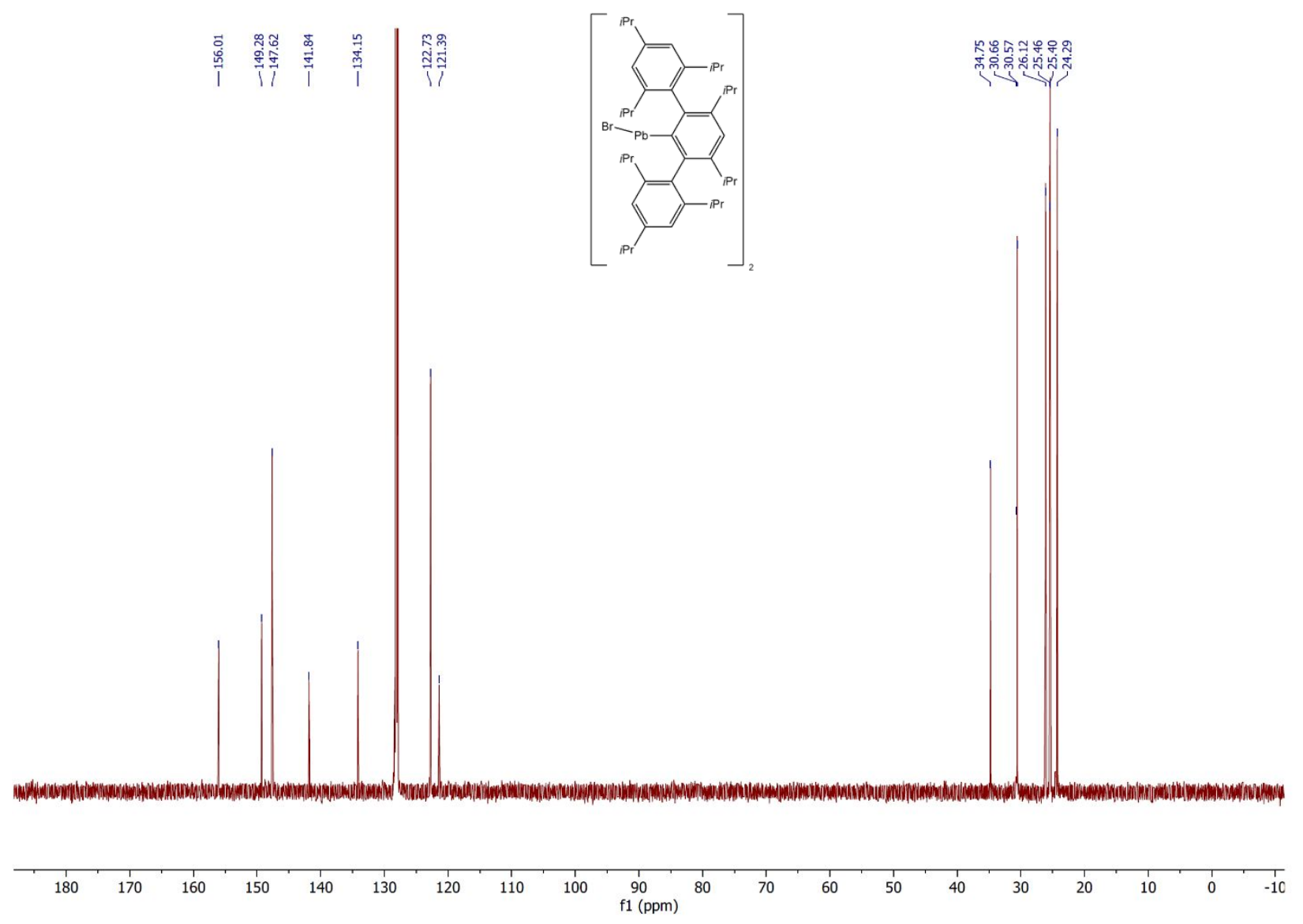

Figure S2. ${ }^{13} \mathrm{C}\left\{{ }^{1} \mathrm{H}\right\}$ NMR spectrum of $\left\{\mathrm{Pb}(\mu-\mathrm{Br}) \mathrm{Ar}^{\mathrm{Pr}^{i}}\right\}_{2}(2)$ in $\mathrm{C}_{6} \mathrm{D}_{6}$ at $25^{\circ} \mathrm{C}$. 


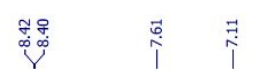
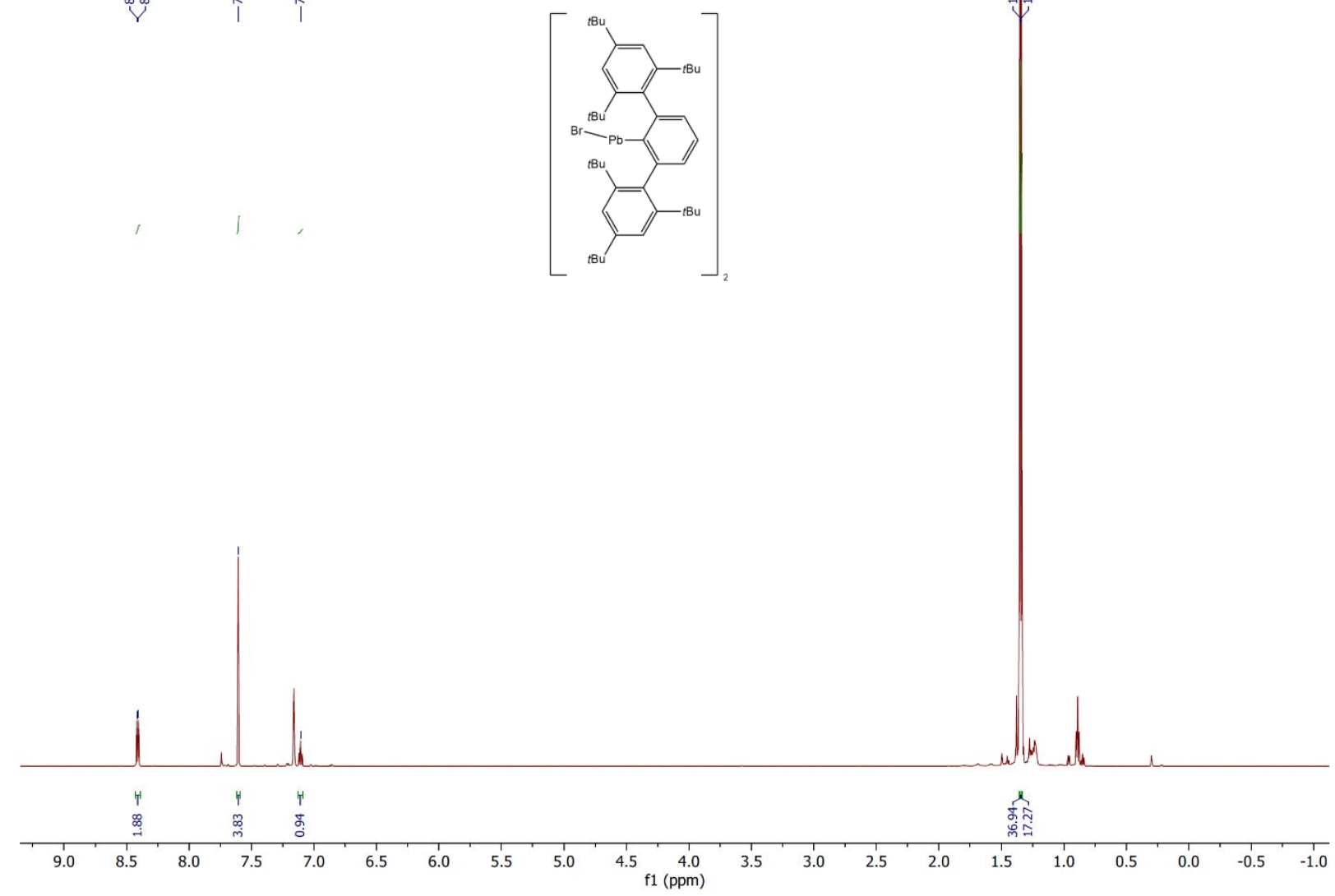

Figure S3. ${ }^{1} \mathrm{H}$ NMR spectrum of $\left\{\mathrm{Pb}(\mu-\mathrm{Br}) \mathrm{Ar}^{\mathrm{Bu}^{t}}\right\}_{2}(3)$ in $\mathrm{C}_{6} \mathrm{D}_{6}$ at $25^{\circ} \mathrm{C}$. 


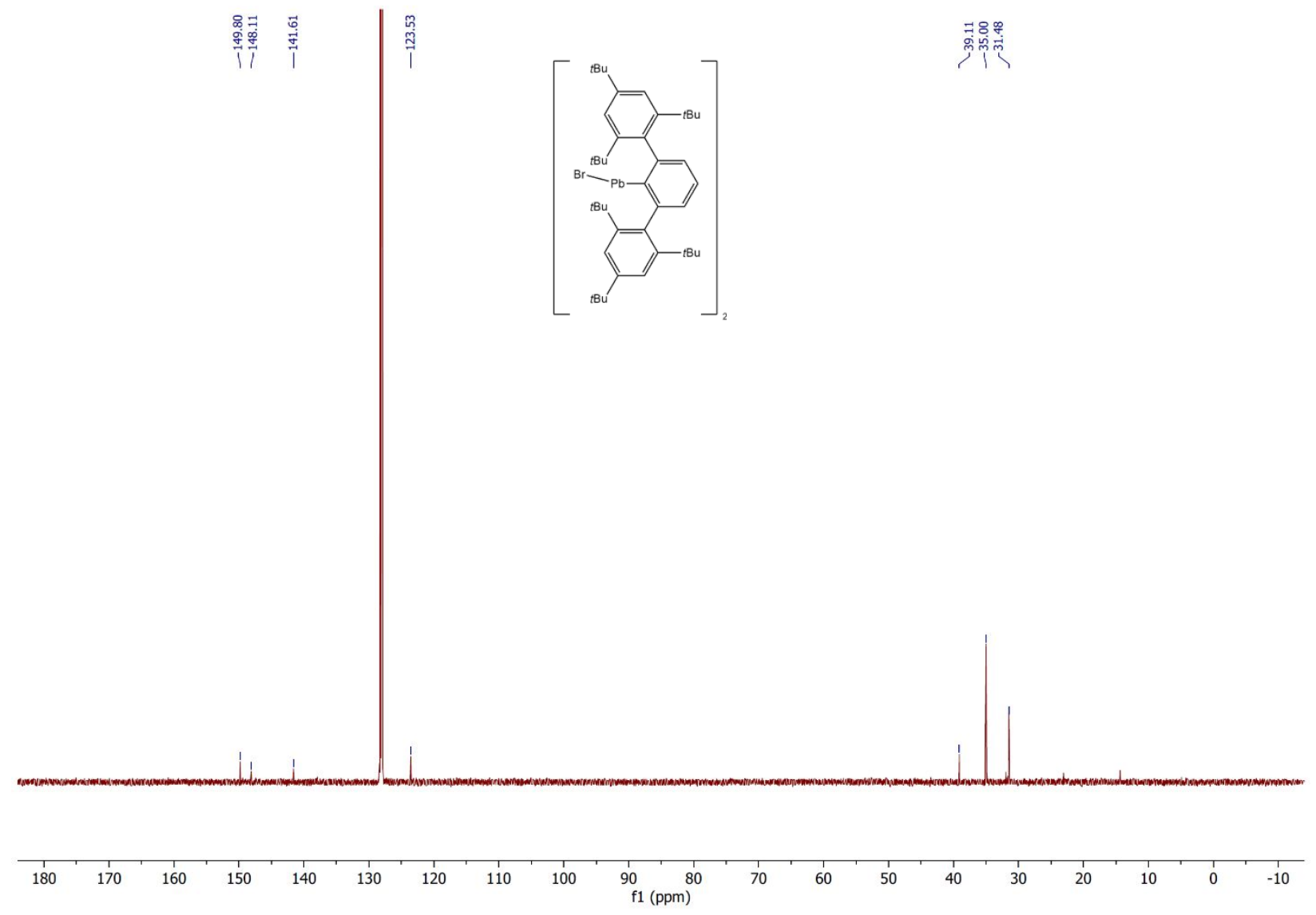

Figure S4. ${ }^{13} \mathrm{C}\left\{{ }^{1} \mathrm{H}\right\}$ NMR spectrum of $\left\{\mathrm{Pb}(\mu-\mathrm{Br}) \mathrm{Ar}^{\mathrm{Bu}}{ }_{6}^{t}\right\}_{2}(3)$ in $\mathrm{C}_{6} \mathrm{D}_{6}$ at $25^{\circ} \mathrm{C}$. 


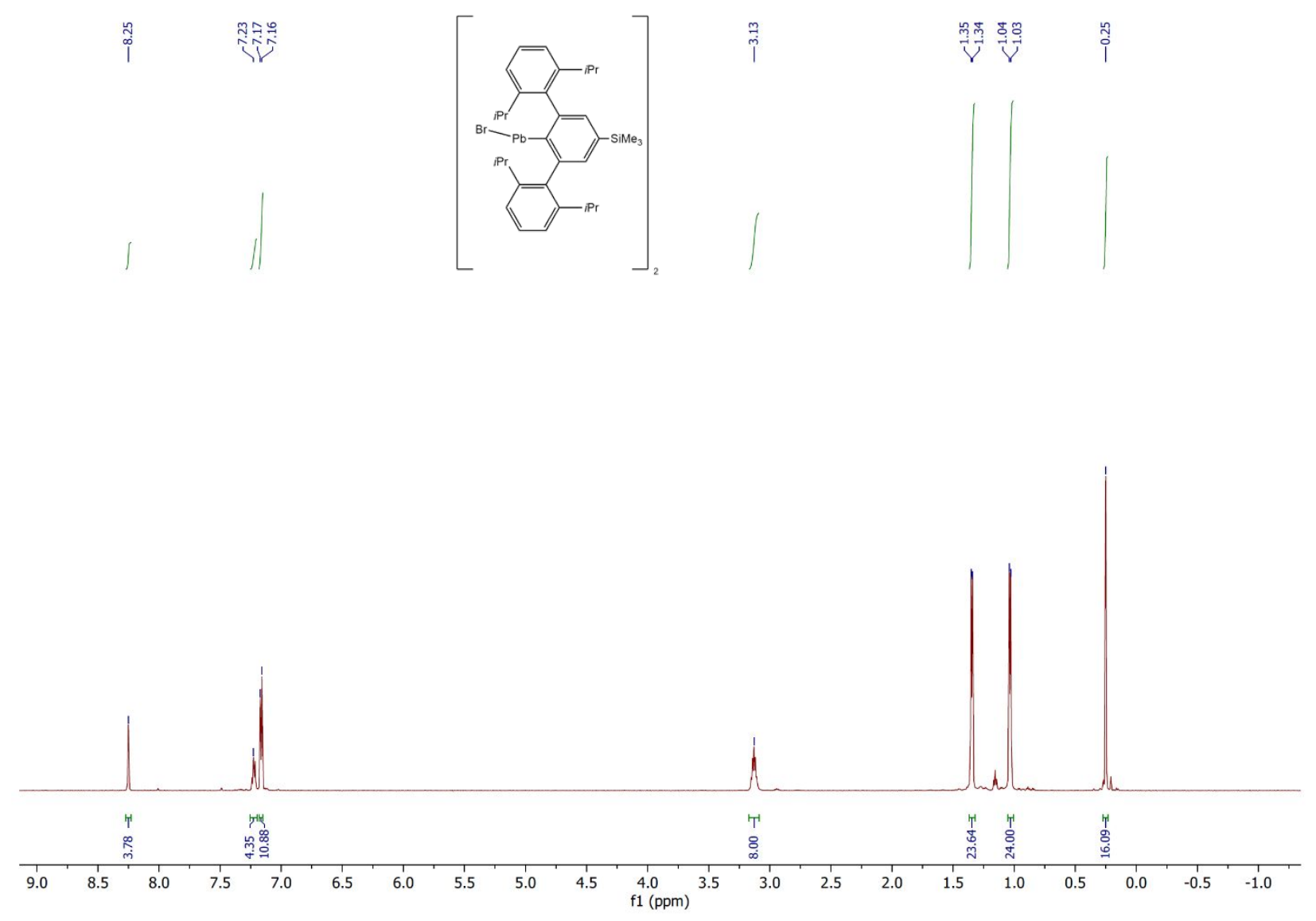

Figure S5. ${ }^{1} \mathrm{H}$ NMR spectrum of $\left\{\mathrm{Pb}(\mu-\mathrm{Br})\left(4-\mathrm{SiMe}_{3}-\mathrm{Ar}^{\mathrm{Pr}^{i}}\right)\right\}_{2}(4)$ in $\mathrm{C}_{6} \mathrm{D}_{6}$ at $25^{\circ} \mathrm{C}$. 


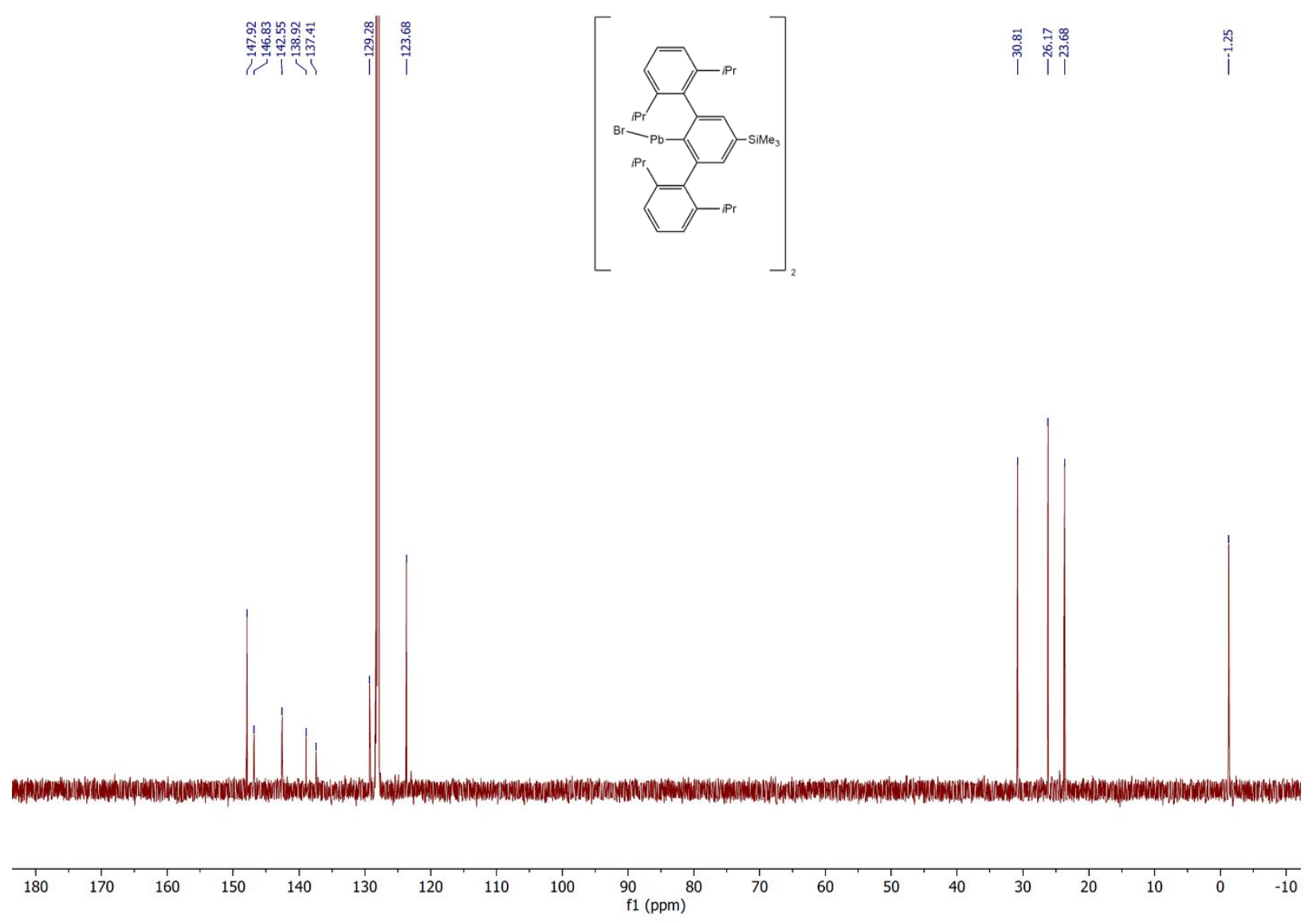

Figure S6. ${ }^{13} \mathrm{C}\left\{{ }^{1} \mathrm{H}\right\}$ NMR spectrum of $\left\{\mathrm{Pb}(\mu-\mathrm{Br})\left(4-\mathrm{SiMe}_{3}-\mathrm{Ar}^{\mathrm{Pr}^{i}}{ }_{4}\right)\right\}_{2}(4)$ in $\mathrm{C}_{6} \mathrm{D}_{6}$ at $25^{\circ} \mathrm{C}$ 


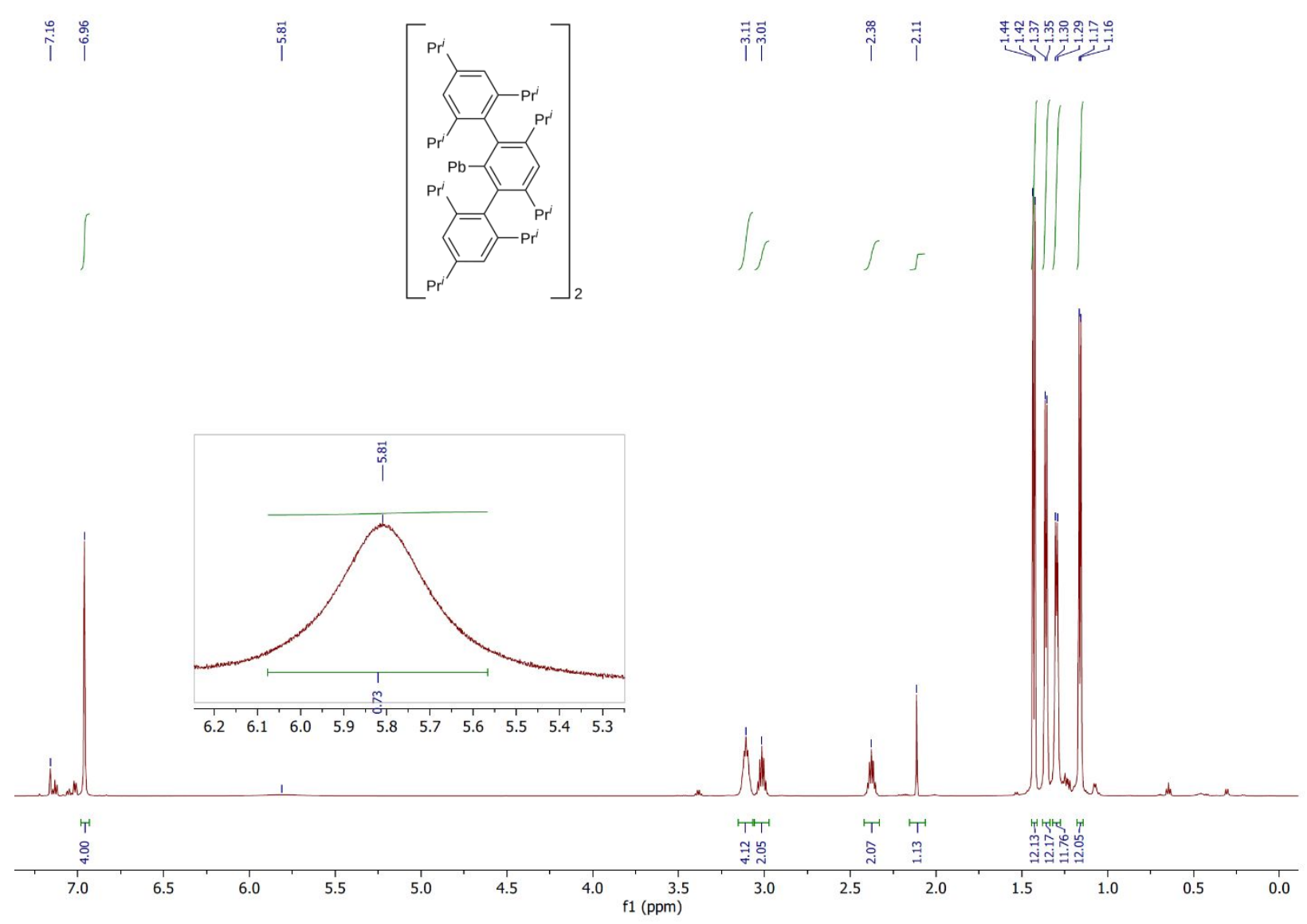

Figure S7. ${ }^{1} \mathrm{H}$ NMR spectrum of $\left(\mathrm{PbAr}^{\mathrm{Pr}^{i}}\right)_{2}(\mathbf{5})$ in $\mathrm{C}_{6} \mathrm{D}_{6}$ at $25^{\circ} \mathrm{C}$. Inset shows the resonance of the para$\mathrm{H}$ on the central aryl ring. 

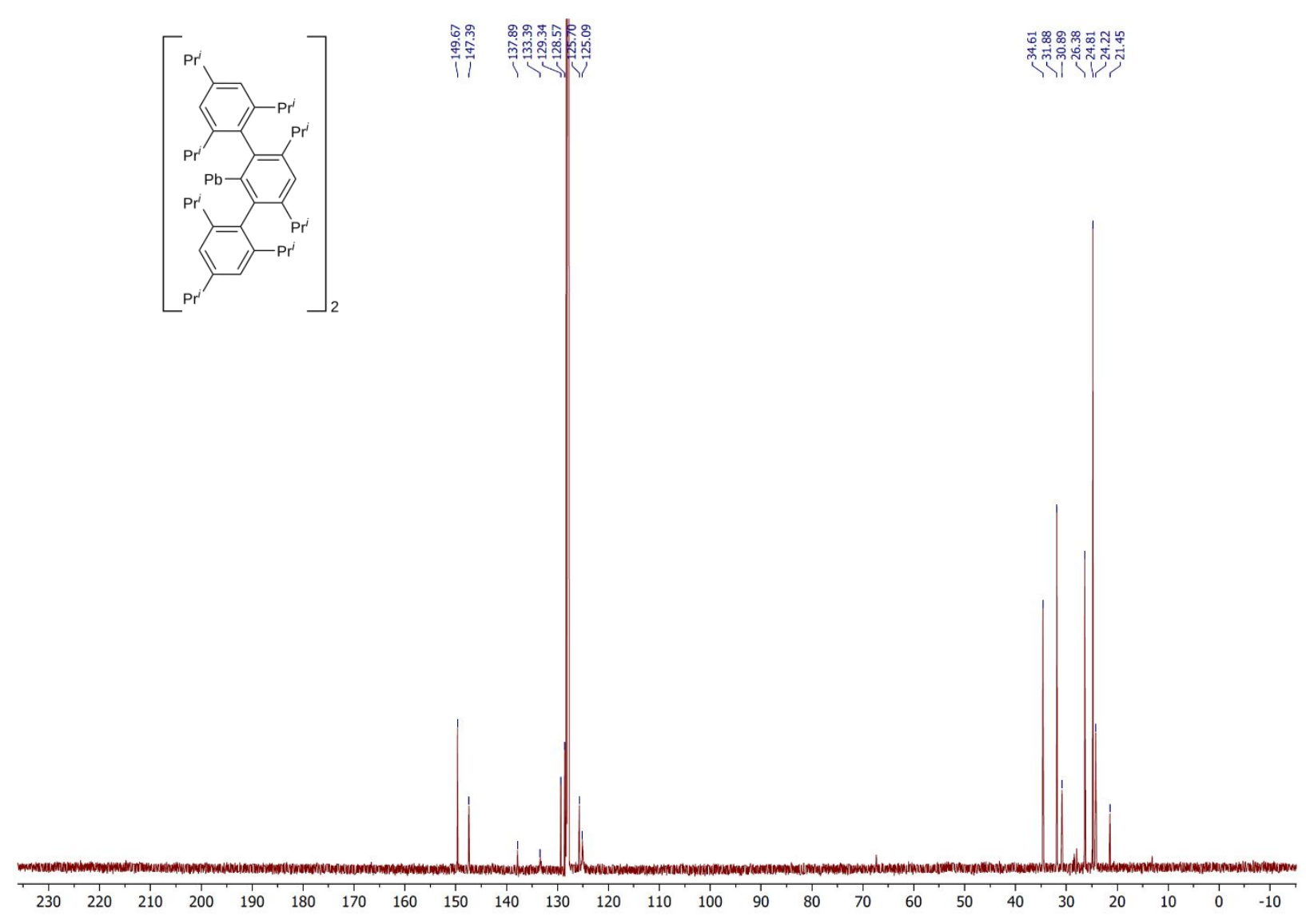

Figure S8. ${ }^{13} \mathrm{C}\left\{{ }^{1} \mathrm{H}\right\}$ NMR spectrum of $\left(\mathrm{PbAr}^{\mathrm{Pr}}{ }_{8}\right)_{2}(\mathbf{5})$ in $\mathrm{C}_{6} \mathrm{D}_{6}$ at $25^{\circ} \mathrm{C}$ 

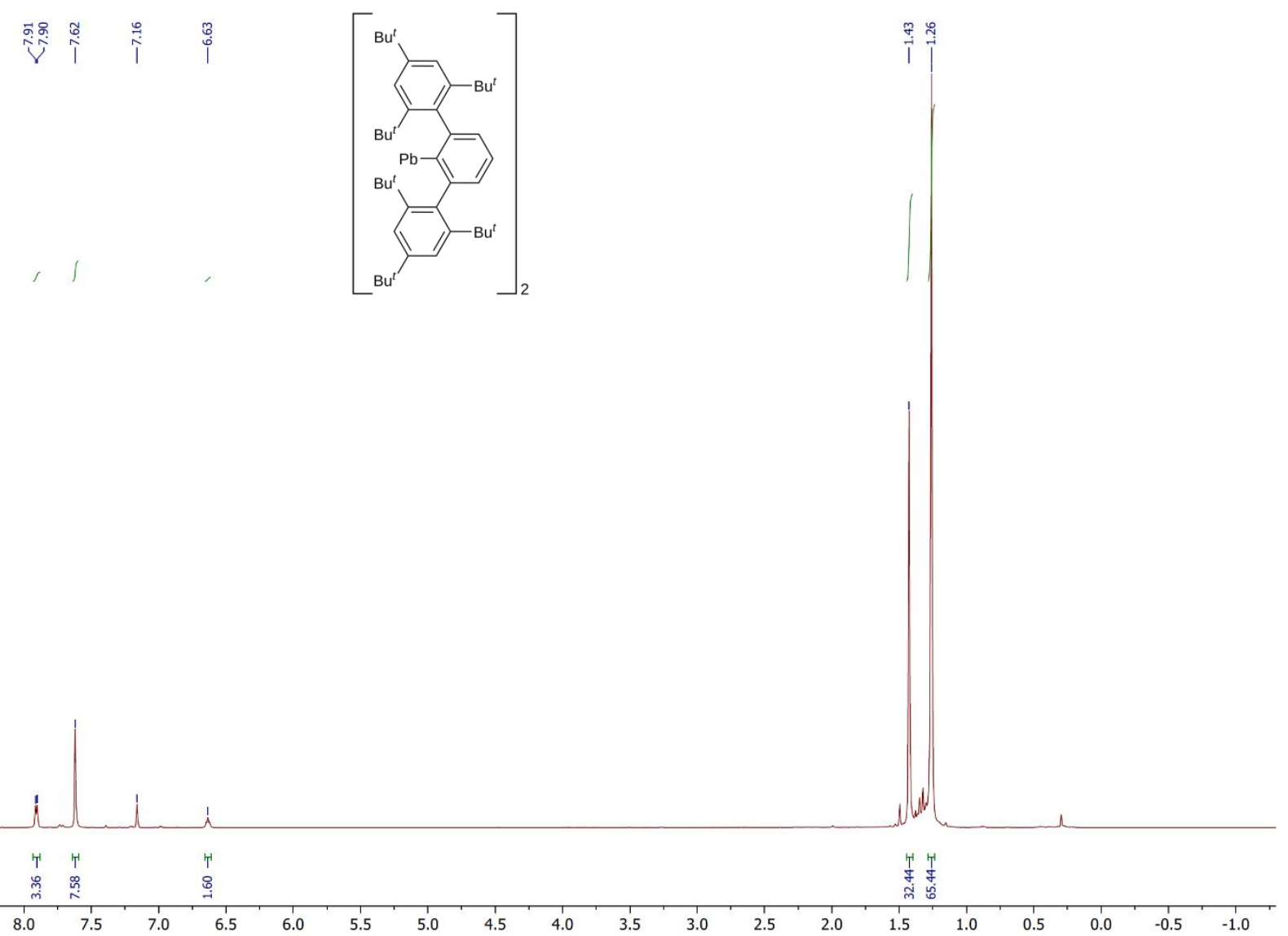

Figure S9. ${ }^{1} \mathrm{H} \mathrm{NMR}$ spectrum of $\left(\mathrm{PbAr}^{\mathrm{Bu}}{ }_{6}^{t}\right)_{2}(6)$ in $\mathrm{C}_{6} \mathrm{D}_{6}$ at $25^{\circ} \mathrm{C}$. 

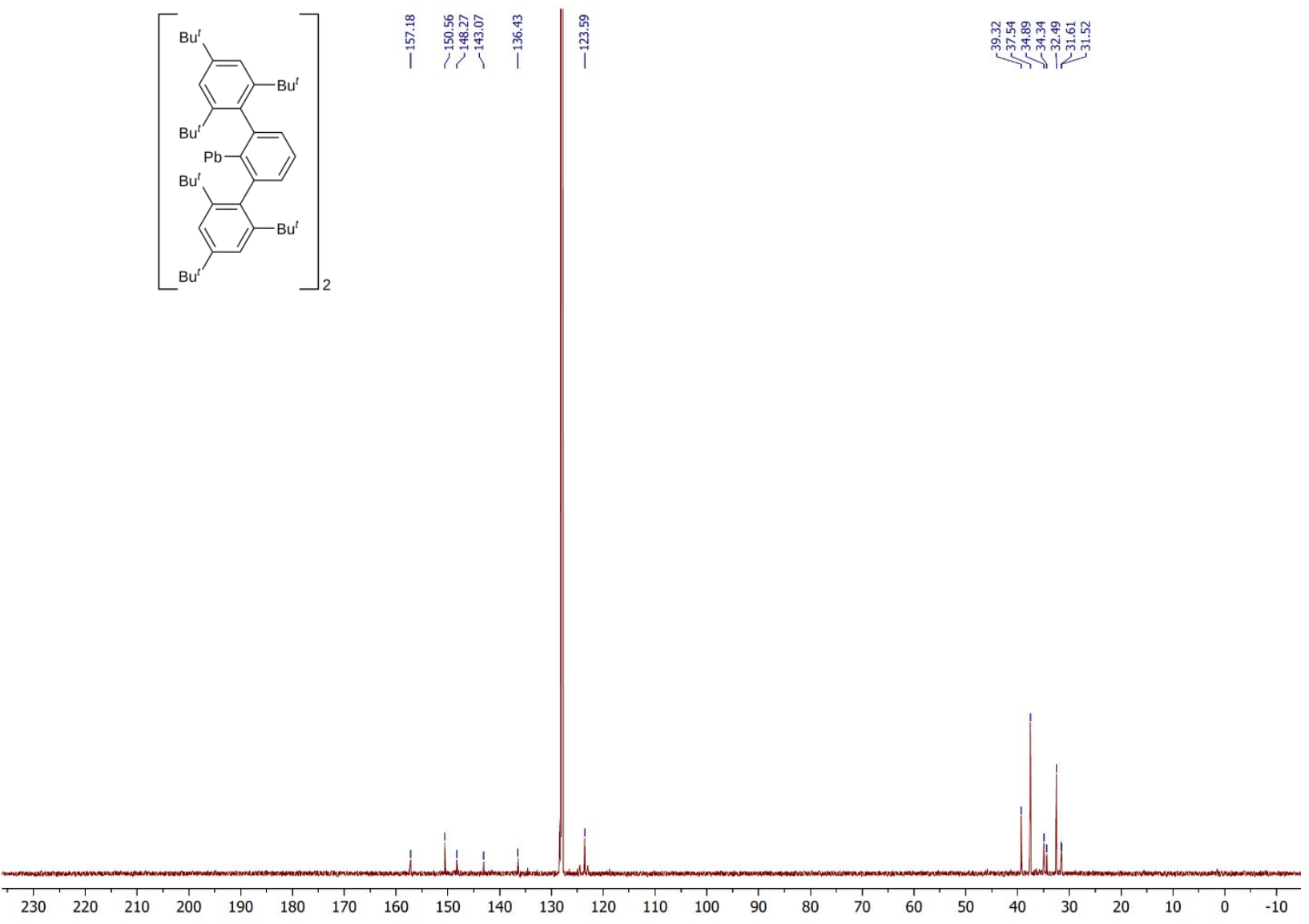

Figure S10. ${ }^{13} \mathrm{C}\left\{{ }^{1} \mathrm{H}\right\}$ NMR spectrum of $\left(\mathrm{PbAr}^{\mathrm{Bu}^{\mathrm{t}}}\right)_{2}(6)$ in $\mathrm{C}_{6} \mathrm{D}_{6}$ at $25^{\circ} \mathrm{C}$ 


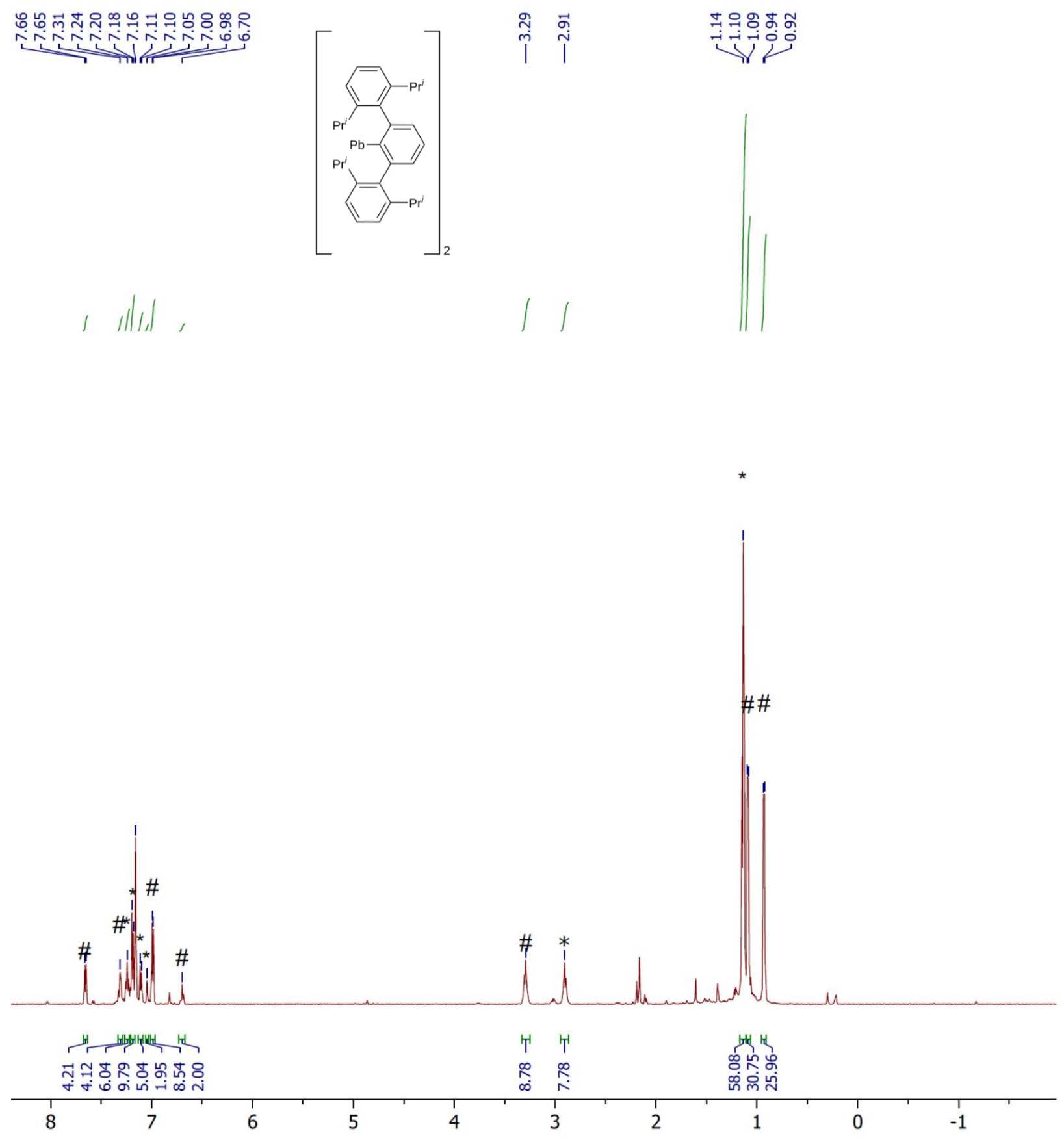

Figure S11. ${ }^{1} \mathrm{H}$ NMR spectrum of $\left(\mathrm{PbAr}^{\mathrm{Pr}^{i}}\right)_{2}(7, \#)+\mathrm{Ar}^{\mathrm{Pr}^{i}} 4 \mathrm{H}(*)$ in $\mathrm{C}_{6} \mathrm{D}_{6}$ at $25^{\circ} \mathrm{C}$ 


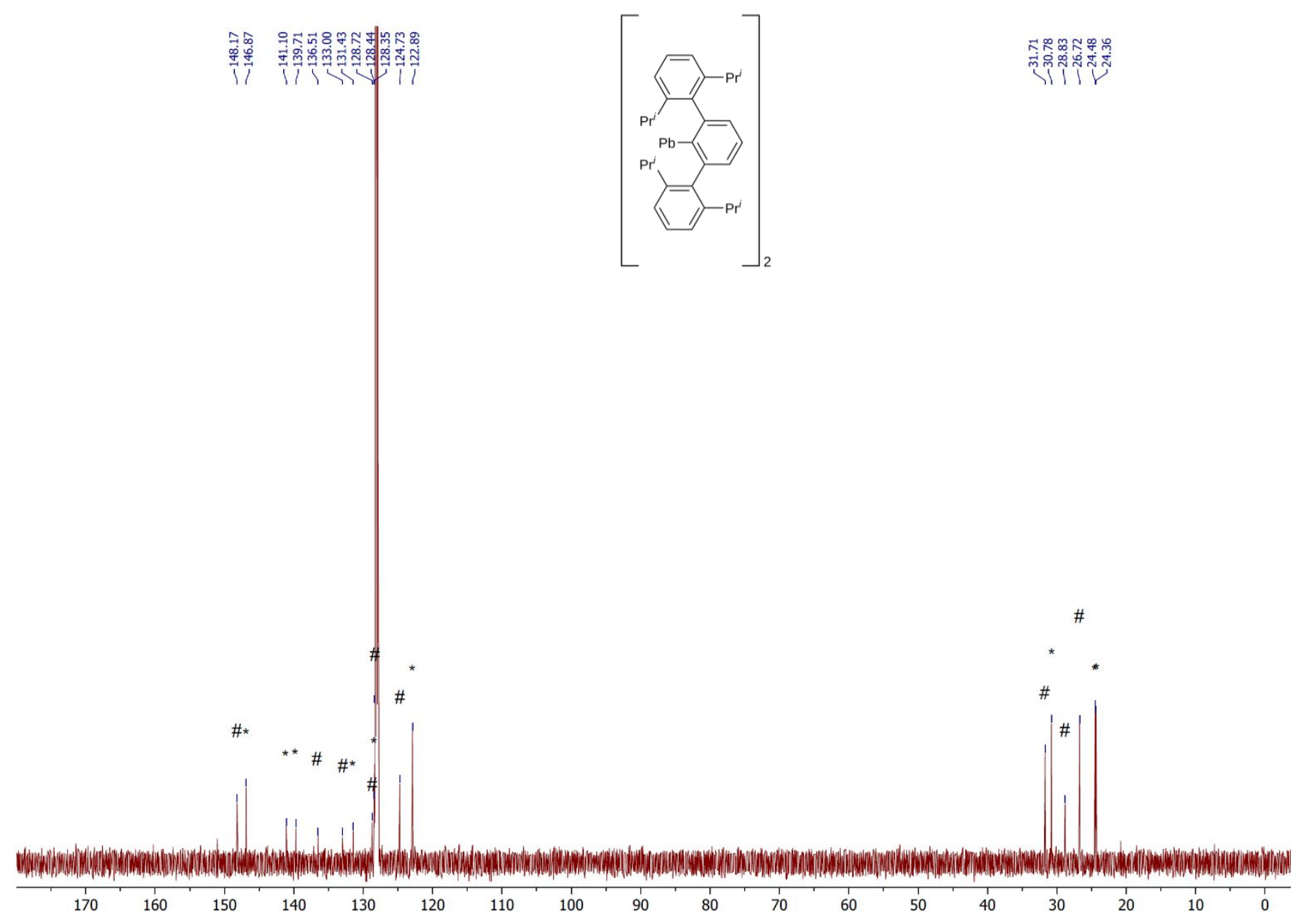

Figure S12. ${ }^{13} \mathrm{C}\left\{{ }^{1} \mathrm{H}\right\}$ NMR of $\left(\mathrm{PbAr}^{\mathrm{Pr}^{i}}\right)_{2}(7, \#)+\mathrm{Ar}^{\mathrm{Pr}}{ }_{4}^{i} \mathrm{H}(*)$ in $\mathrm{C}_{6} \mathrm{D}_{6}$ at $25^{\circ} \mathrm{C}$ 


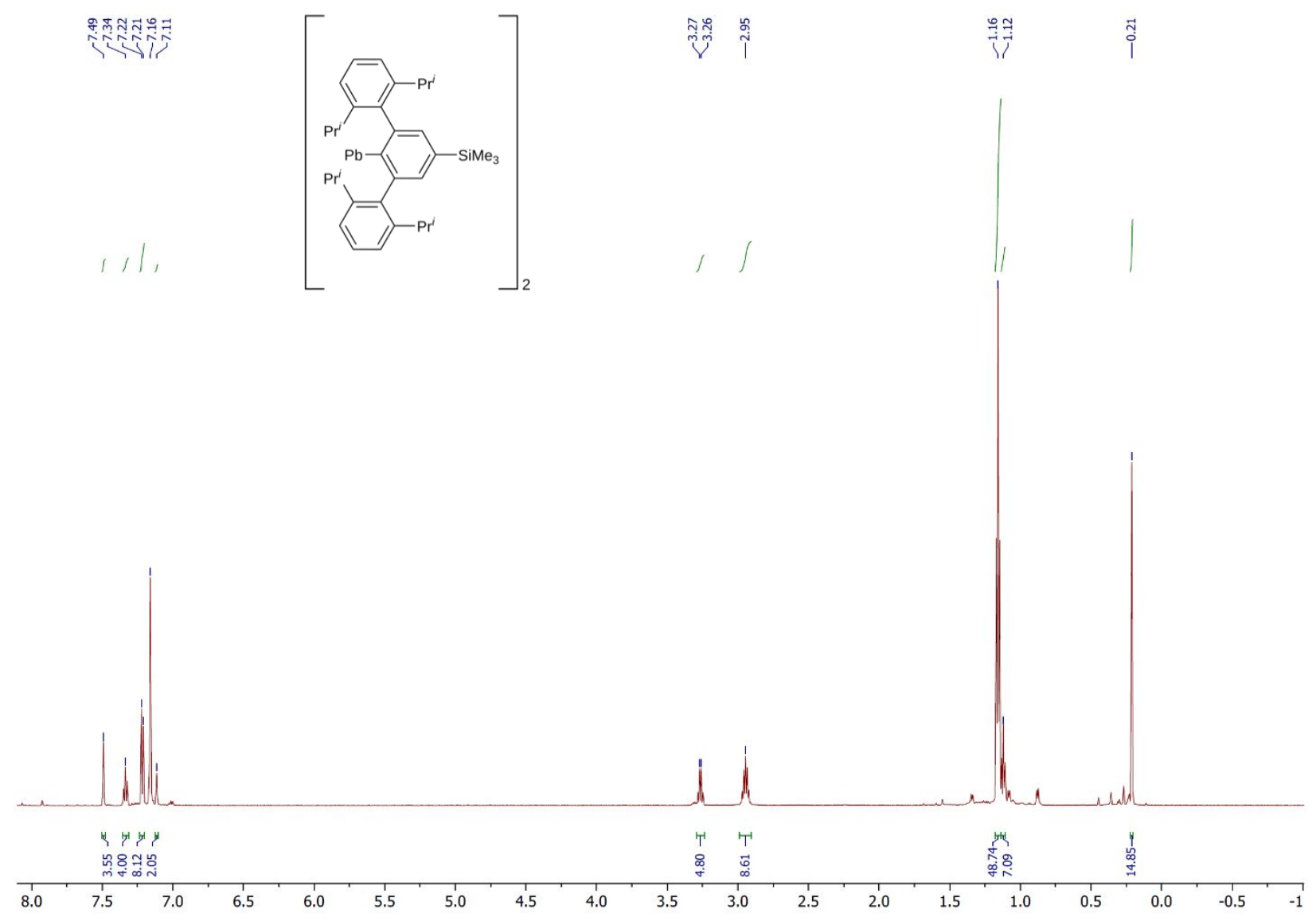

Figure S13. ${ }^{1} \mathrm{H}$ NMR spectrum of $\left\{\mathrm{Pb}\left(4-\mathrm{SiMe}_{3}-\mathrm{Ar}^{\mathrm{Pr}^{i}}\right)\right\}_{2}\left(\mathbf{8} \cdot \mathrm{Et}_{2} \mathrm{O}\right)$ in $\mathrm{C}_{6} \mathrm{D}_{6}$ at $25^{\circ} \mathrm{C}$. 

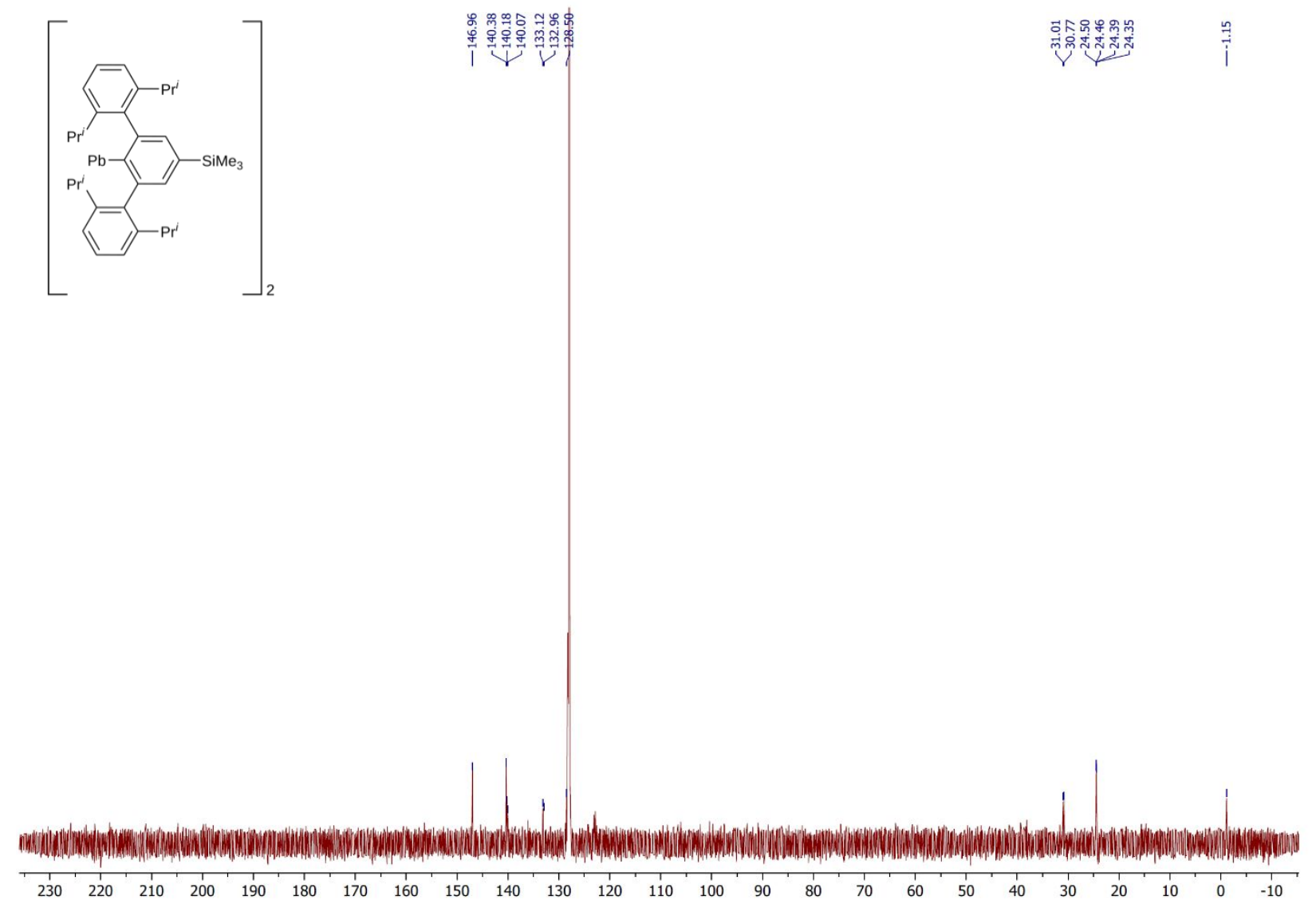

Figure S14. ${ }^{13} \mathrm{C}\left\{{ }^{1} \mathrm{H}\right\}$ NMR spectrum of $\left\{\mathrm{Pb}\left(4-\mathrm{SiMe}_{3}-\mathrm{Ar}^{\mathrm{Pr}^{i}}\right)\right\}_{2}\left(\mathbf{8} \cdot \mathrm{Et}_{2} \mathrm{O}\right)$ in $\mathrm{C}_{6} \mathrm{D}_{6}$ at $25^{\circ} \mathrm{C}$. 


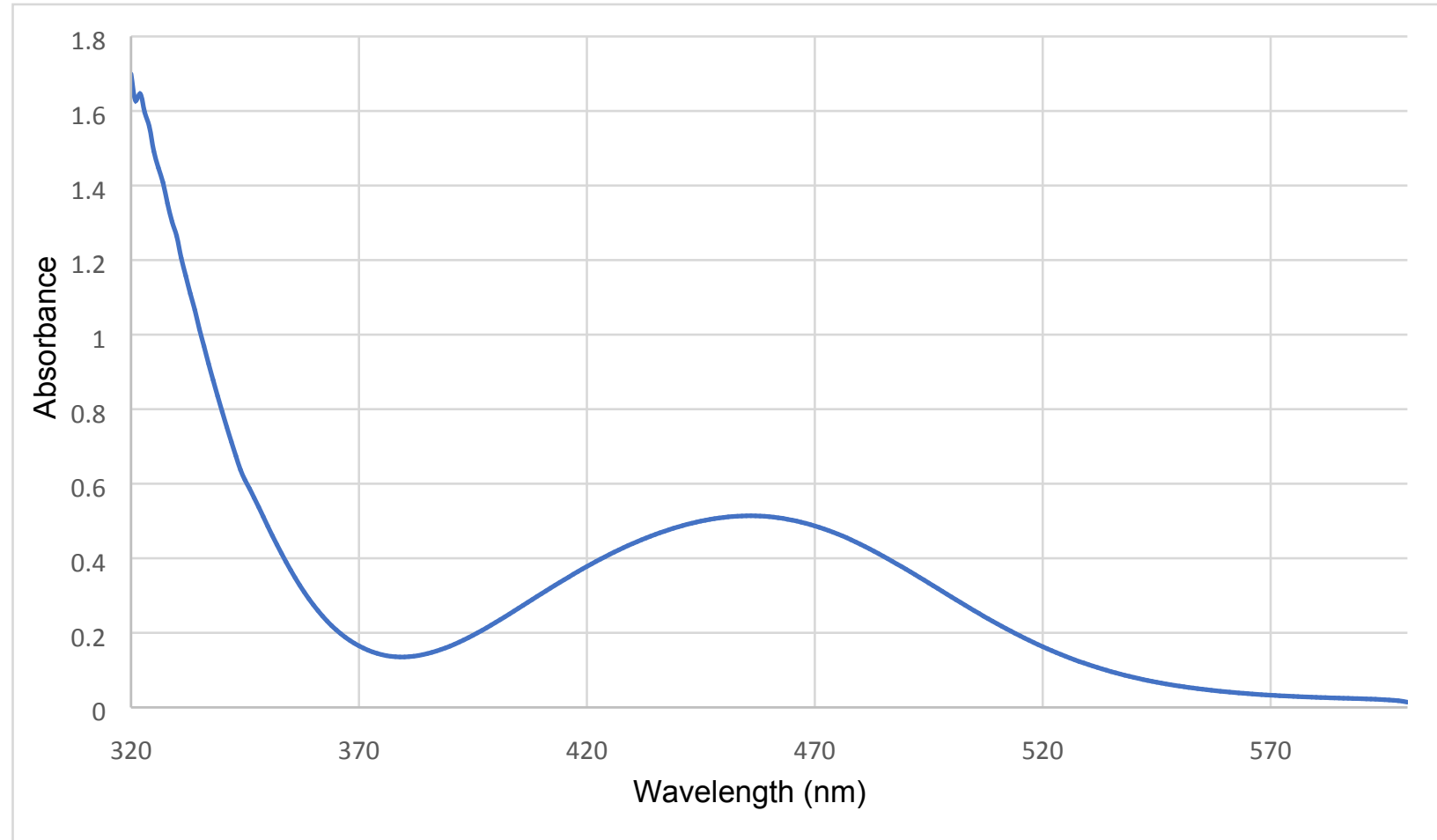

Figure S15. UV-Visible spectrum of $\left\{\mathrm{Pb}(\mu-\mathrm{Br}) \mathrm{Ar}^{\mathrm{Pr}^{\mathrm{i}} 8}\right\}_{2}(2)$ in hexanes $(685 \mu \mathrm{M})$. 


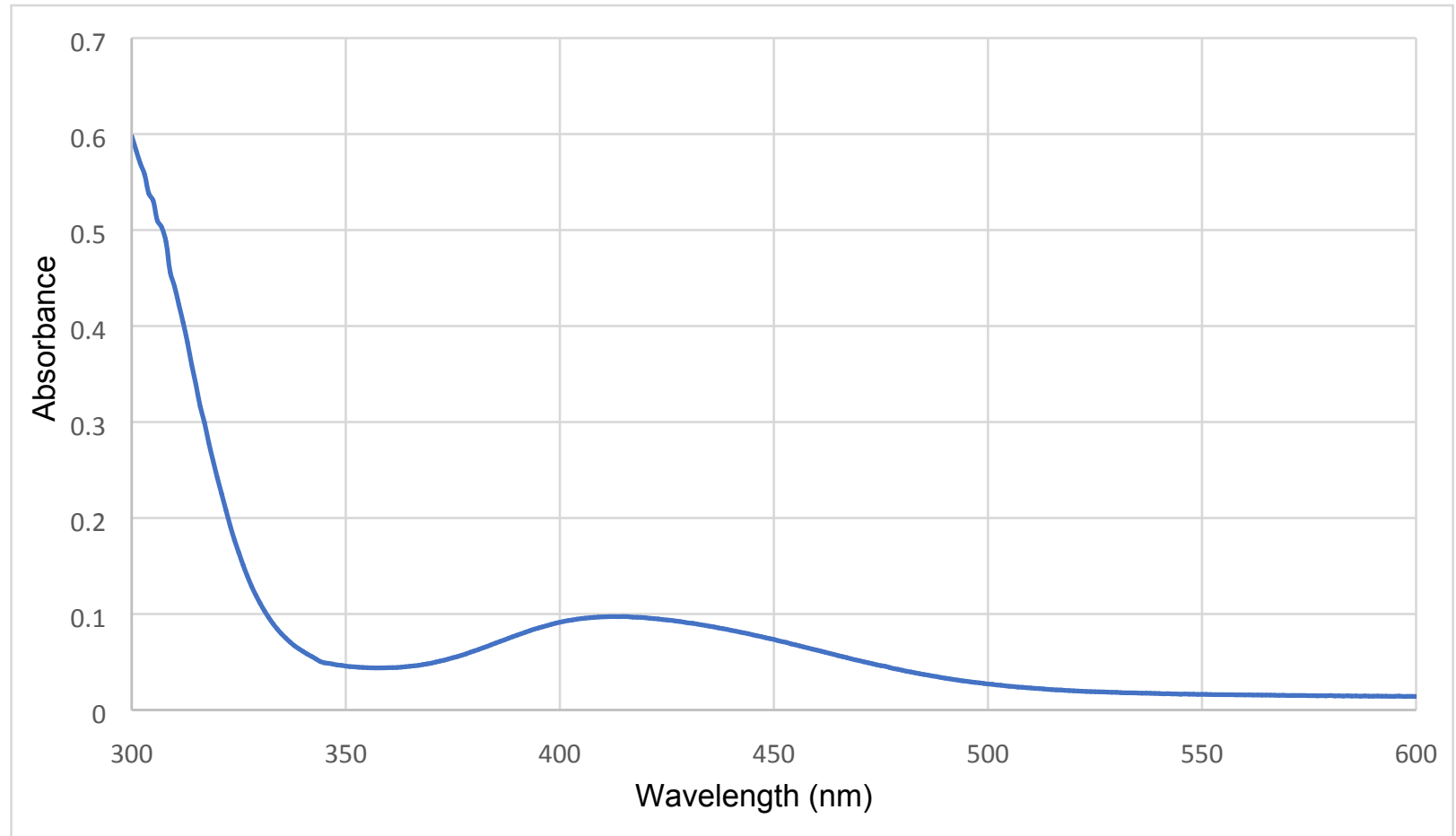

Figure S16. UV-Visible spectrum of $\left\{\mathrm{Pb}(\mu-\mathrm{Br}) \mathrm{Ar}^{\mathrm{Bu}}{ }_{6}^{\mathrm{t}}\right\}_{2}(3)$ in hexanes $(101 \mathrm{mM})$.

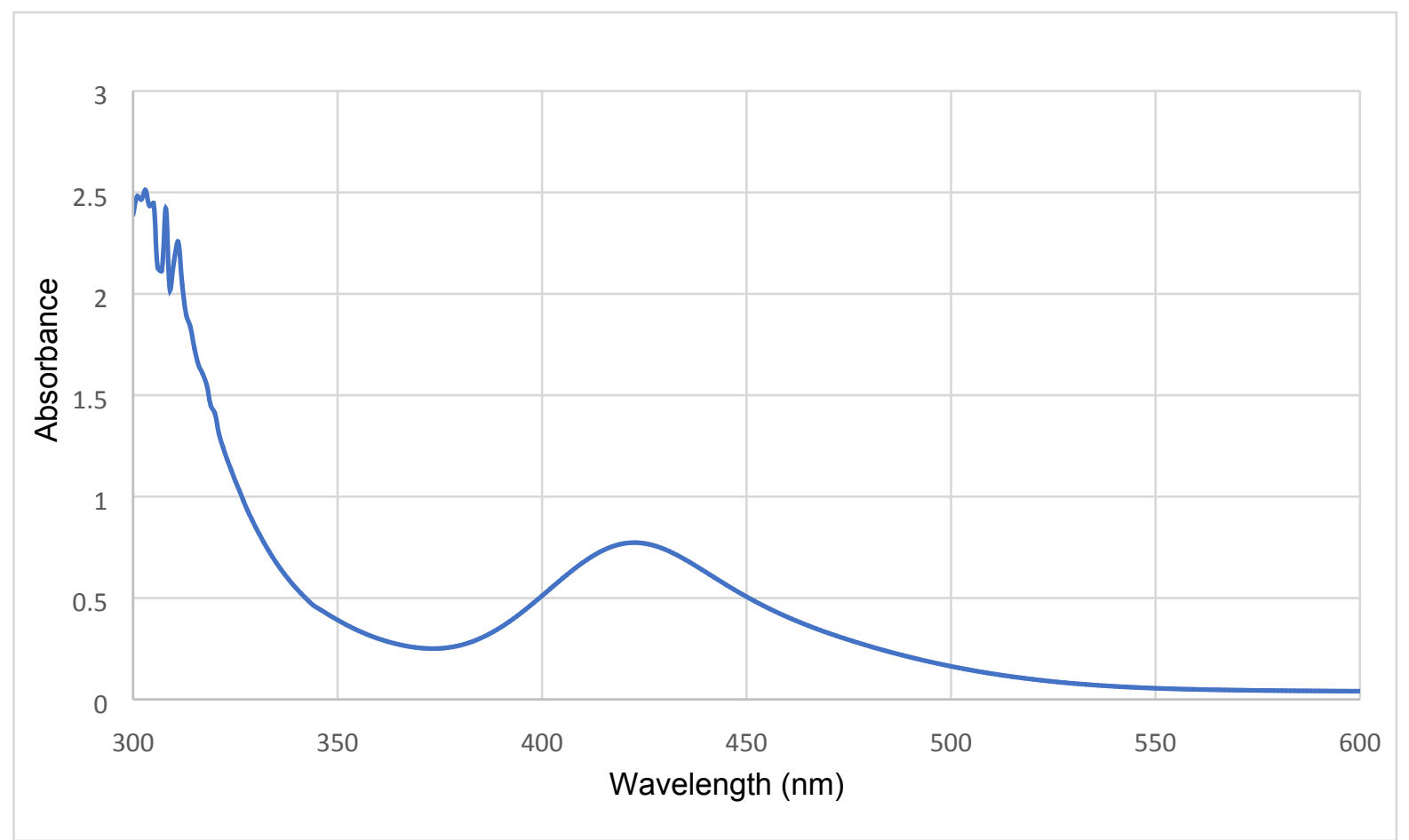

Figure S17. UV-Visible spectrum of $\left\{\mathrm{Pb}(\mu-\mathrm{Br})\left(4-\mathrm{SiMe}_{3}-\mathrm{Ar}^{\mathrm{Pr}^{i}}\right)\right\}_{2}(4)$ in hexanes $(921 \mu \mathrm{M})$. 


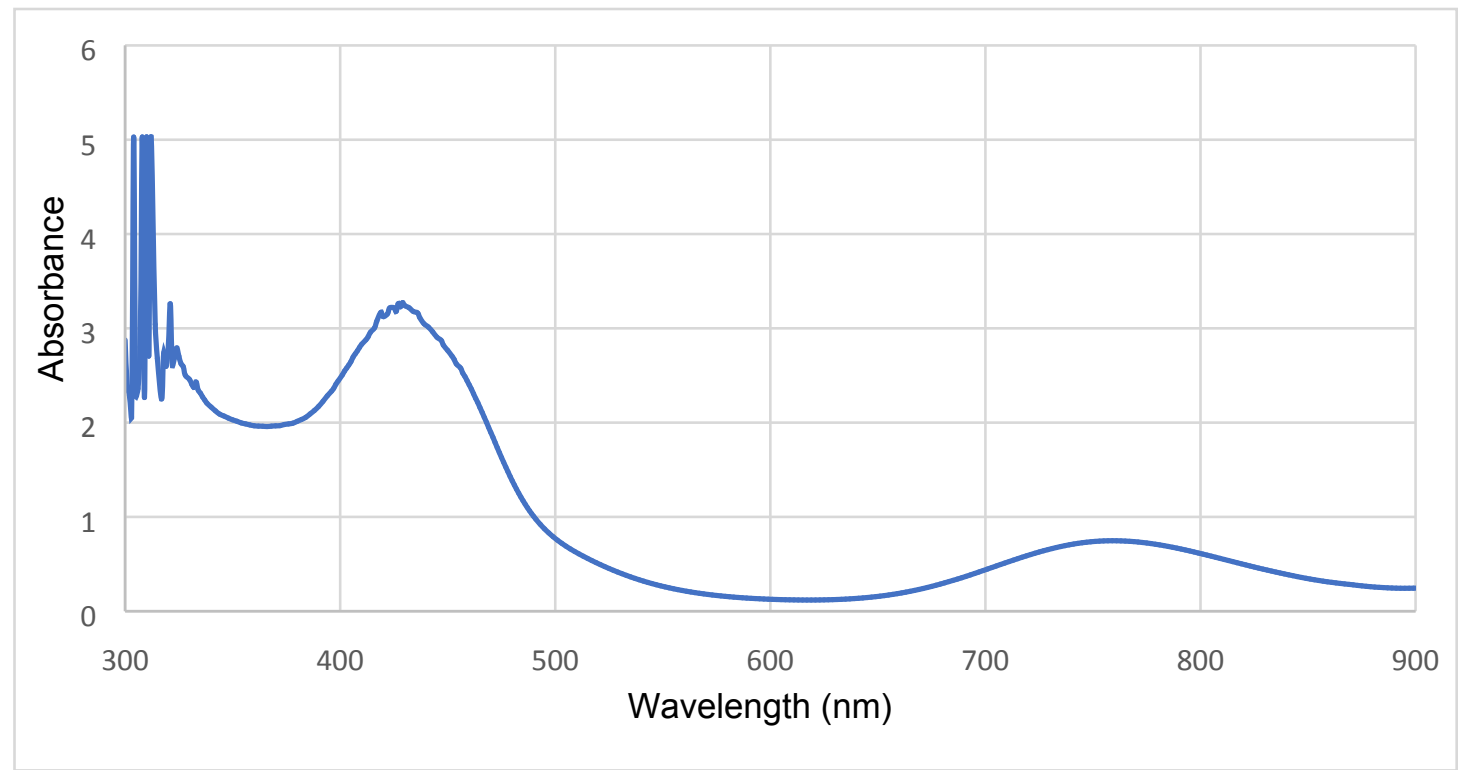

Figure S18. UV-Visible spectrum of $\left(\operatorname{PbAr}^{\mathrm{Pr}^{i}}\right)_{2}(\mathbf{5})$ in hexanes $(280 \mu \mathrm{M})$.

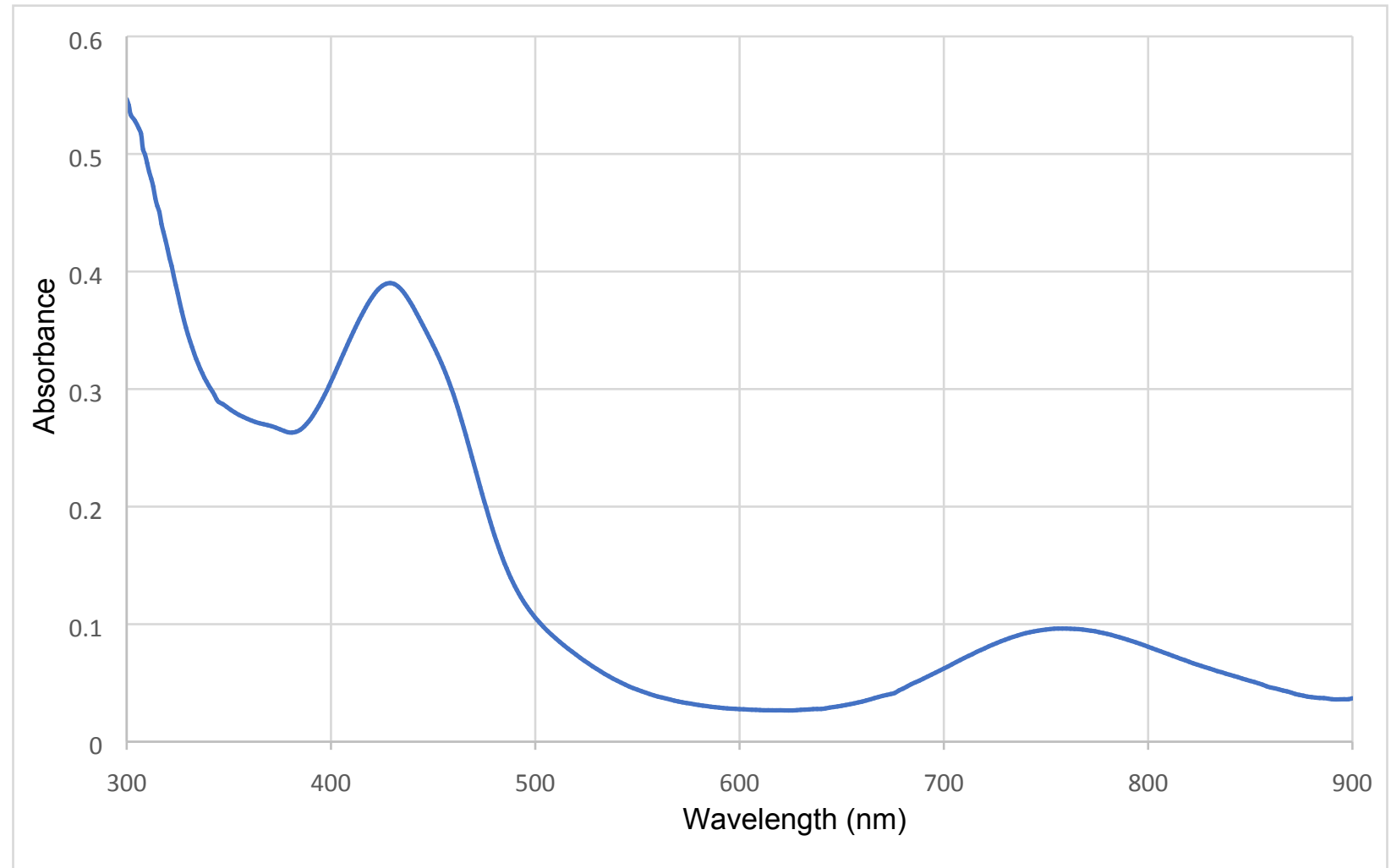

Figure S19. UV-Visible spectrum of $\left(\operatorname{PbAr}^{\mathrm{Pr}^{i}}\right)_{2}(5)$ in hexanes $(42.0 \mu \mathrm{M})$. 


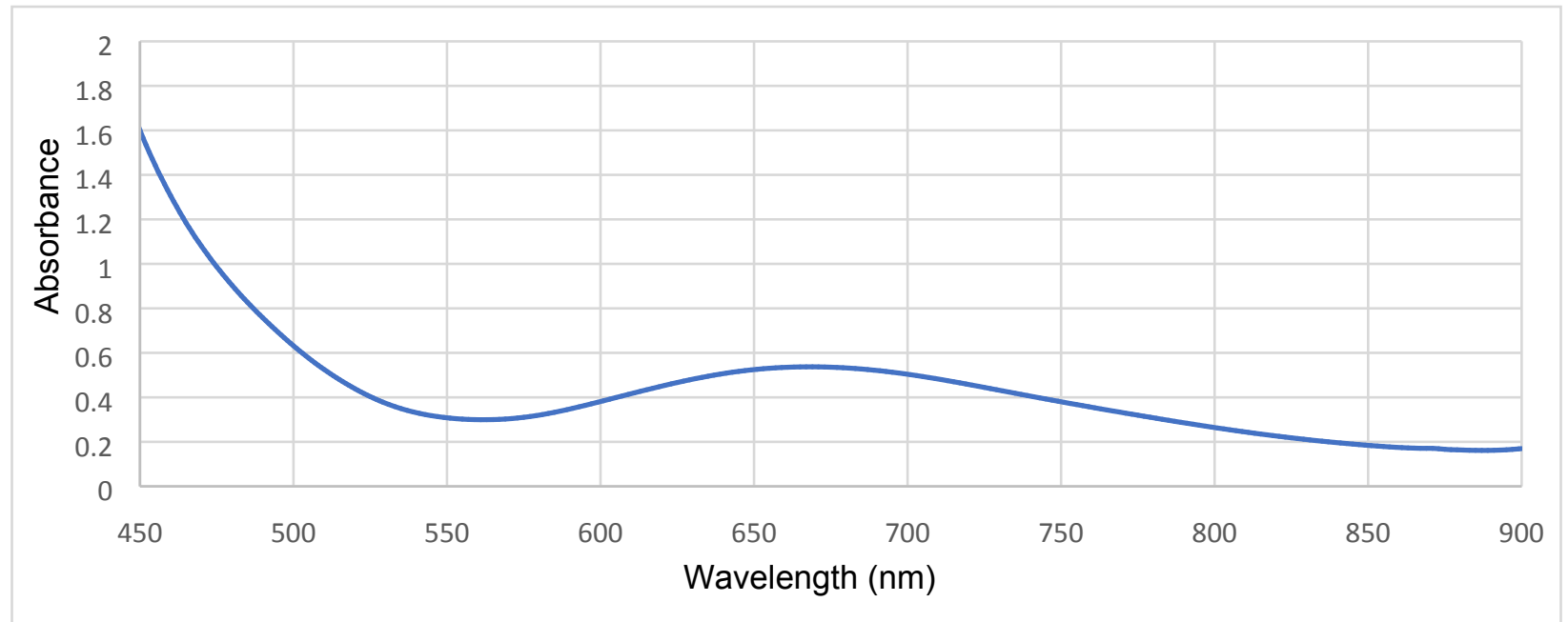

Figure S20. UV-Visible spectrum of $\left(\mathrm{PbAr}^{\mathrm{Bu}^{\mathrm{t}}}\right)_{2}(\mathbf{6})$ in hexanes $(596 \mu \mathrm{M})$

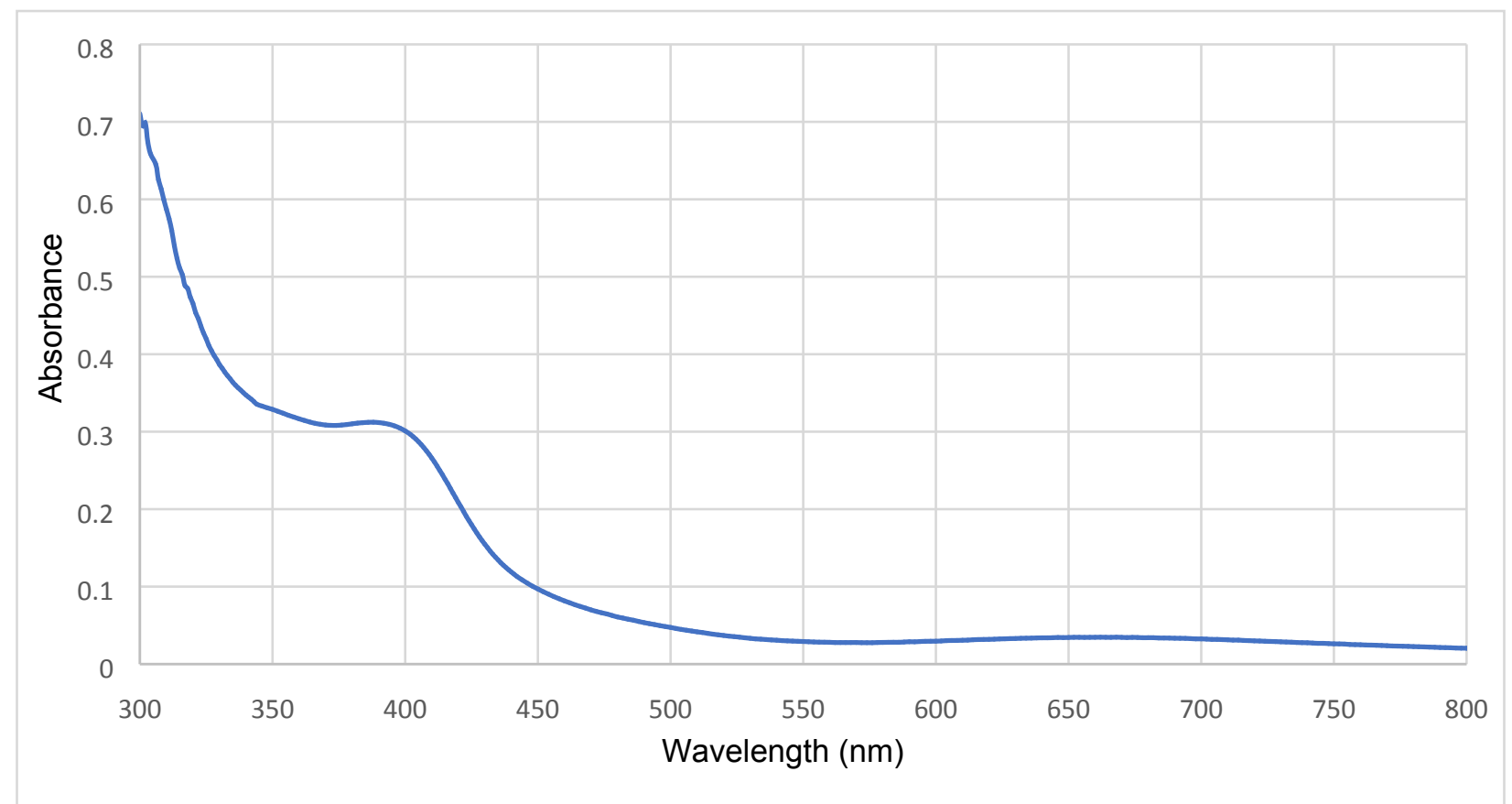

Figure S21. UV-Visible spectrum of $\left(\mathrm{PbAr}^{\mathrm{Bu}^{\mathrm{t}}}\right)_{2}(\mathbf{6})$ in hexanes $(44.7 \mu \mathrm{M})$ 


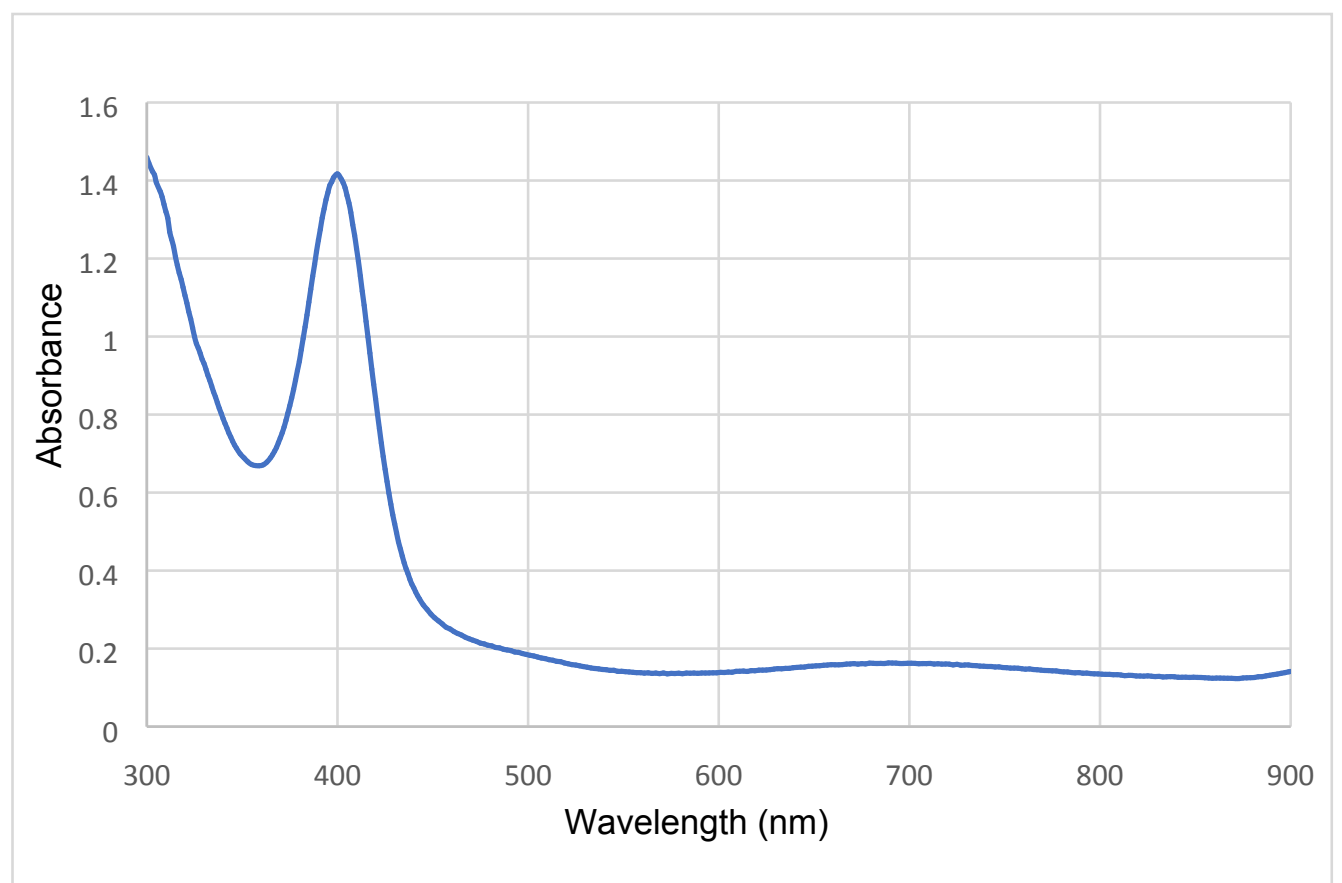

Figure S22. UV-Visible spectrum of $\left(\mathrm{PbAr}^{\mathrm{Pr}_{4}^{i}}\right)_{2}(7)$ in hexanes $(107 \mu \mathrm{M})$

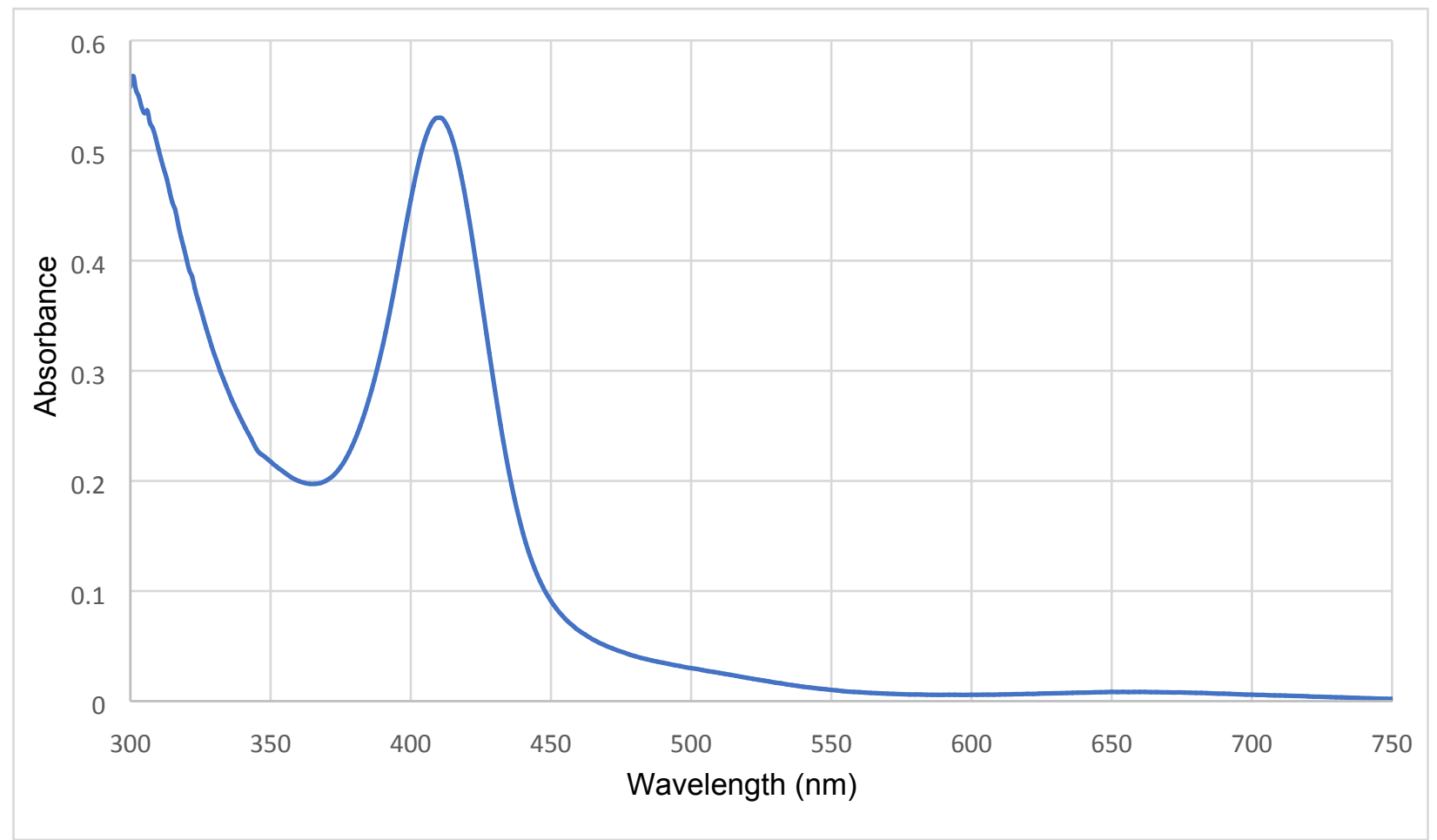

Figure S23. UV-Visible spectrum of $\left\{\mathrm{Pb}\left(4-\mathrm{SiMe}_{3}-\mathrm{Ar}^{\mathrm{Pr}^{i}}\right)\right\}_{2} \mathbf{8} \cdot \mathrm{Et}_{2} \mathrm{O}$ in hexanes $(30.3 \mu \mathrm{M})$. 


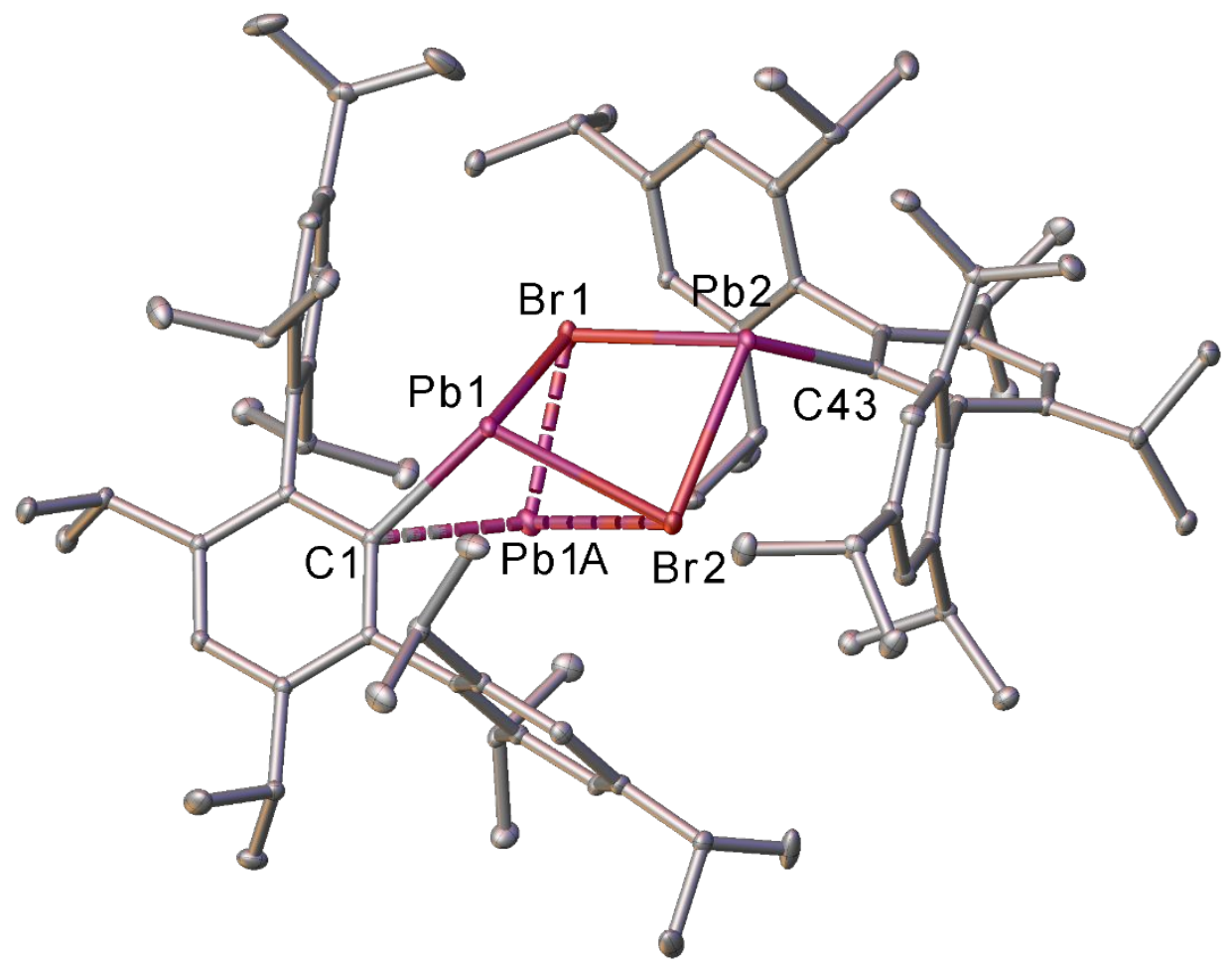

Figure S24. Thermal ellipsoid plot of $\left\{\mathrm{Pb}(\mathrm{Br}) \mathrm{Ar}^{\mathrm{Pr}^{i}}\right\}_{2}$ (2) (30\%). H atoms not shown for clarity. $\mathrm{Pb} 1$ is disordered over two sites with a $1 \%$ occupancy at position $\mathrm{Pb} 1 \mathrm{~A}$. 


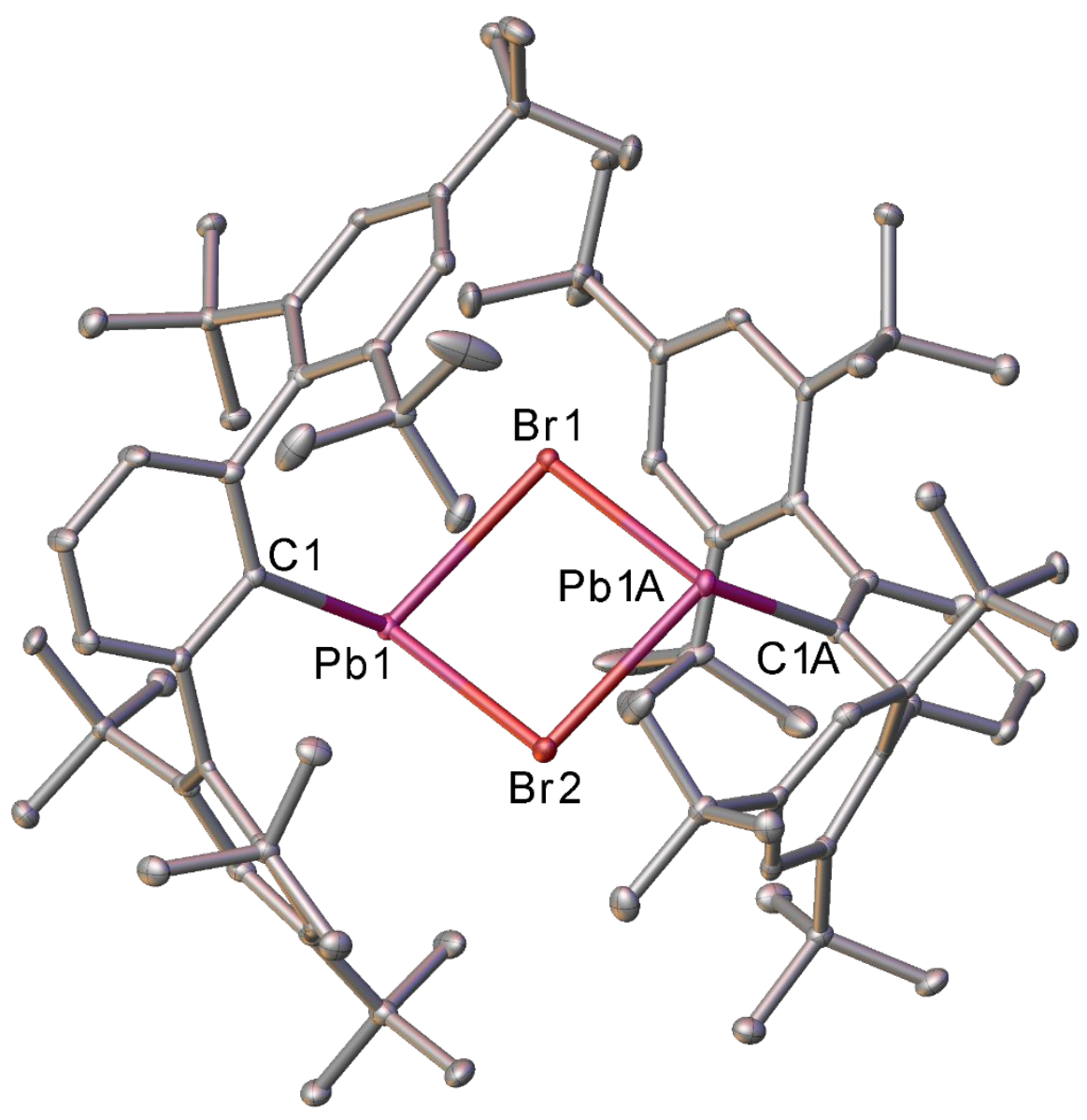

Figure S25. Thermal ellipsoid plot of $\left\{\mathrm{Pb}(\mu-\mathrm{Br}) \mathrm{Ar}^{\mathrm{Bu}^{\mathrm{t}}}\right\}_{2}$ (3) (30\%). H atoms not shown for clarity. 


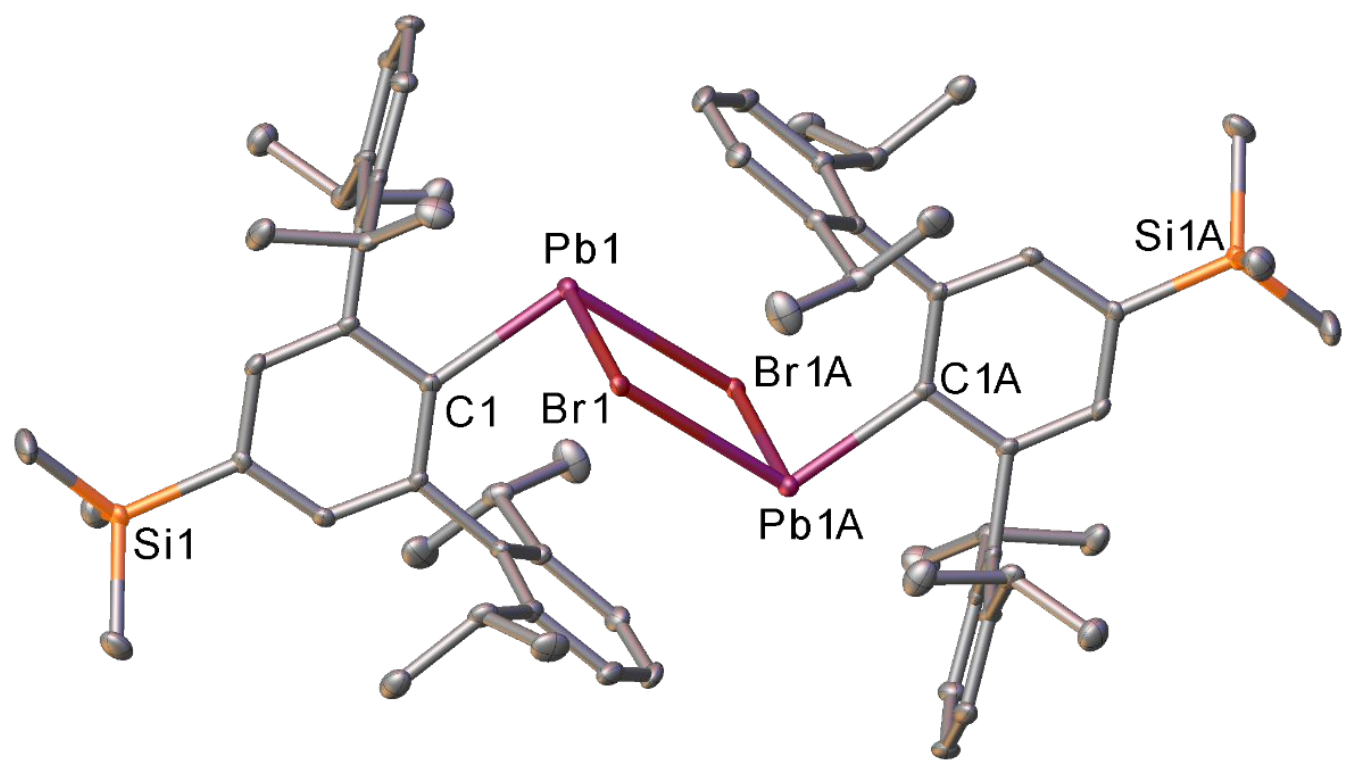

Figure S26. Thermal ellipsoid plot of $\left\{\mathrm{Pb}(\mu-\mathrm{Br})\left(4-\mathrm{SiMe}_{3}-\mathrm{Ar}^{\mathrm{Pr}^{i}} 4\right)\right\}_{2}(4)(30 \%)$. H atoms not shown for clarity. 


\section{Photos of Compounds}

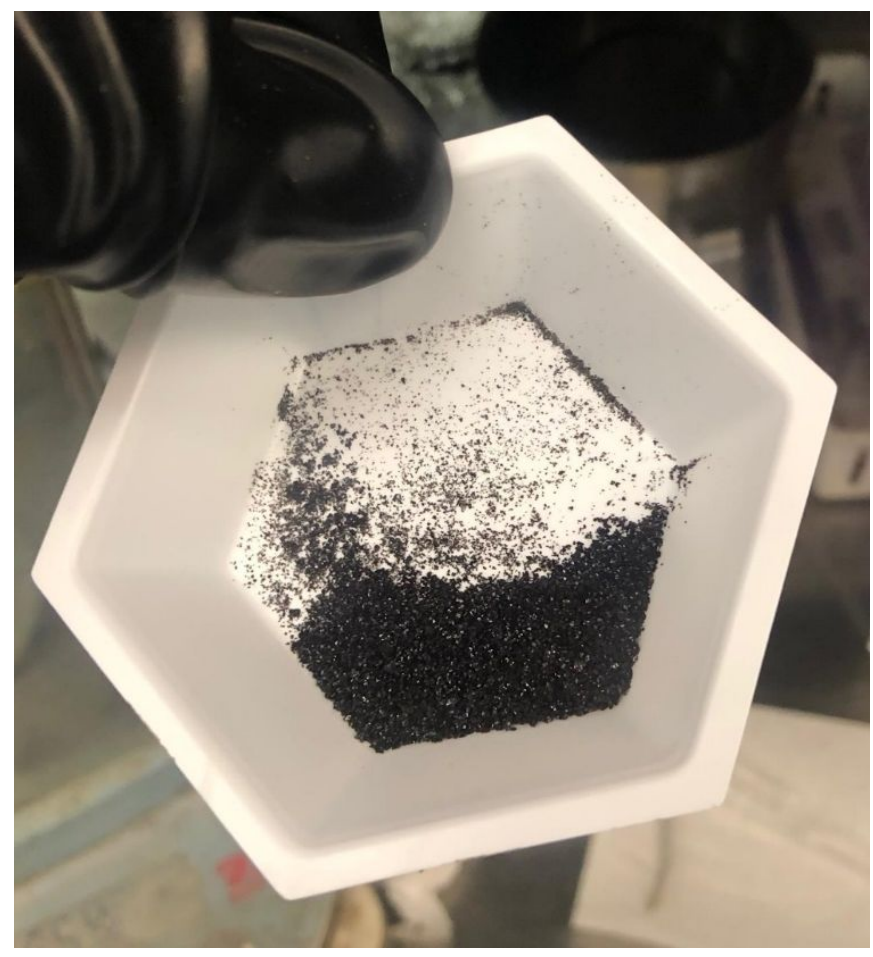

Dark brown crystals of $\mathbf{1}$.

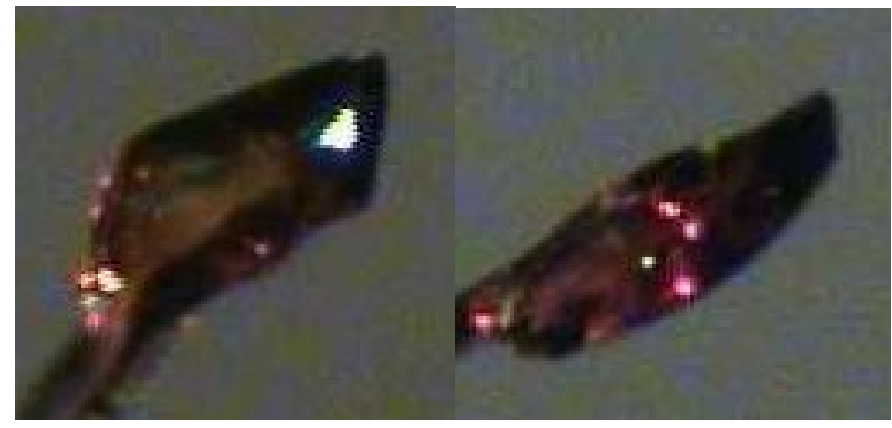

Crystal Images of 5 


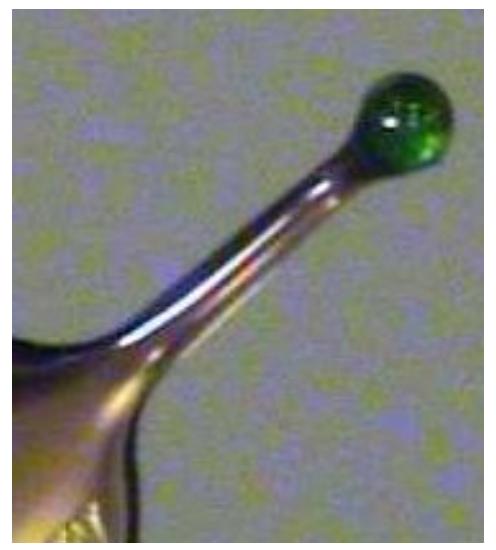

\section{Crystal of 6}

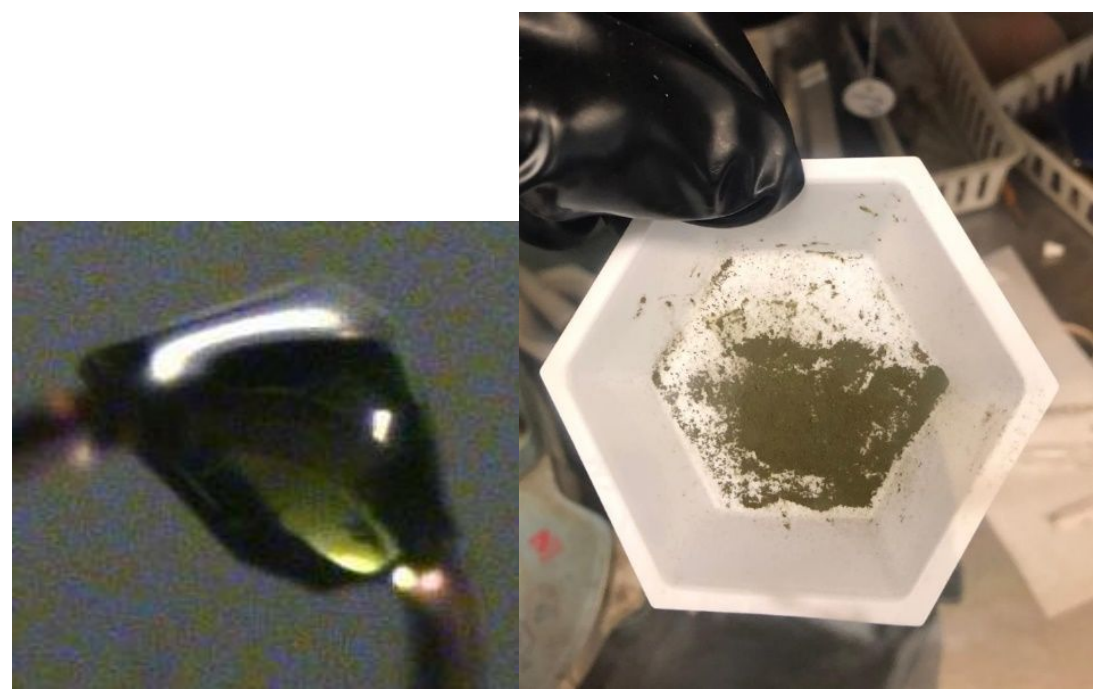

Crystal(left) and powder(right) of 7.
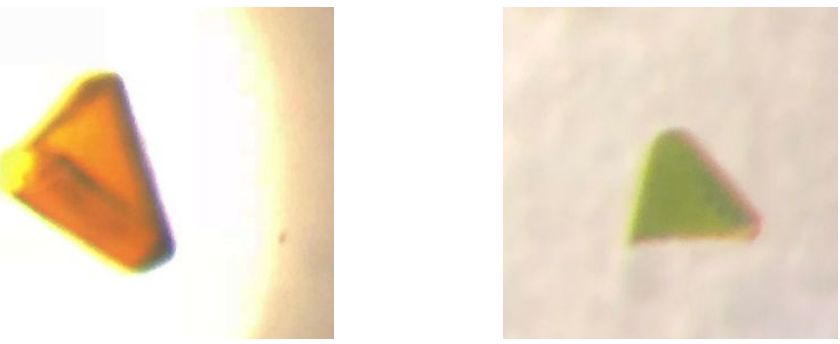

A crystal of $\mathbf{8}$ under a microscope illustrating their dichroic character. 


\section{Computational Details}

\subsection{General remarks, geometry optimizations, energy calculations and vibrational frequency calculations}

All visualizations of structures, MOs and NBOs were created with UCSF Chimera ${ }^{\mathrm{S} 3}$ 1.10.2.

Quantum mechanical calculations were performed with the TURBOMOLE 7.0.2 ${ }^{\mathrm{S} 4, \mathrm{~S} 5}$, ORCA 4. $1^{\mathrm{S} 6, \mathrm{~S} 7}$ and $\mathrm{xtb} 6.1 .0^{\mathrm{S} 8}$ program packages unless otherwise stated. ${ }^{\mathrm{S} 5, \mathrm{S9}, \mathrm{S} 10}$ Geometries were pre-optimized with the GFN2-xTB ${ }^{\mathrm{S} 11}$ extended tight binding method and finally optimized using the TPSS ${ }^{\mathrm{S} 12}$ meta-GGA functional in combination with the triple- $\zeta$ def2-TZVPS13 basis set. The numerical quadrature grid $\mathrm{m} 4$ grid was employed for the integration of the exchange-correlation contributions and default convergence criteria for energies and gradients were applied as implemented in TURBOMOLE. The default StuttgartDresden effective core potential ecp- $46^{\mathrm{S} 14}$ was applied for all $\mathrm{Pb}$ atoms. All structures were preoptimized applying the fast and robust GFN2-xTB ${ }^{\mathrm{S} 11}$ Tight-Binding quantum mechanical method. Minimum structures were verified as minima on the potential energy hyper surface by the absence of imaginary frequencies $\left(i \omega>35 \mathrm{~cm}^{-1}\right)$ in the harmonic frequency calculation. Imaginary frequencies below this threshold were inverted and included in the thermostatistical correction calculation.

All geometry optimizations and single point energy calculations were performed applying the resolution-of-identity (RI) approximation for Coulomb integrals ${ }^{\mathrm{S} 15}$ with matching default auxiliary basis sets. ${ }^{\text {S16 }}$ The $\mathrm{D}^{\mathrm{S} 17}$ and $\mathrm{D} 4(\mathrm{EEQ})^{\mathrm{S} 18, \mathrm{~S} 19}$ dispersion correction schemes applying Becke-Johnson (BJ) damping ${ }^{\mathrm{S} 20, \mathrm{~S} 21}$ and including Axilrod-Teller-Muto (ATM) ${ }^{\mathrm{S} 22, \mathrm{~S} 23}$ type three-body dispersion to the total dispersion energy was applied (D3(BJ)-ATM generally applied for geometry optimizations). For a review on this topic see Ref. S24

Ro-vibrational corrections to obtain free energies were obtained from a modified rigid rotor harmonic oscillator statistical treatment ${ }^{\mathrm{S} 25}\left(T=25.0^{\circ} \mathrm{C}, 1 \mathrm{~atm}\right.$ pressure $)$ based on harmonic frequencies calculated at the geometry optimization level (TPSS-D3(BJ)-ATM/def2-TZVP). To avoid errors in the harmonic approximation, frequencies with wave numbers below $100 \mathrm{~cm}^{-1}$ were treated partially as rigid rotors. ${ }^{\mathrm{S} 25}$

Final gas phase single point energies were calculated with the PBE0 ${ }^{\mathrm{S} 26}$ and $\mathrm{B} 3 \mathrm{LYP} \mathrm{P}^{\mathrm{S} 27}$ hybrid functionals with the large polarized quadruple- $\zeta$ Gaussian AO basis set def2-TZVPP ${ }^{S 13}$ and the $\mathrm{m} 5$ grid.

\subsection{Solvation corrections and Gibbs free energies}

Solvation effects were further considered by the COSMO-RS ${ }^{\mathrm{S} 28, \mathrm{~S} 29}$ model, used as implemented in COSMOtherm (Version C3.0, release 16.01) ${ }^{\mathrm{S} 30}$ with the 2016 parameterization for toluene (parameter file: BP_TZVP_C30_1601.ctd; default $\mathrm{G}_{\text {solv }}$ option). Calculated solvation corrections were further corrected for the volume work of 1 bar to $1 \mathrm{M}$ ideal gas. The default $\mathrm{BP} 86^{\mathrm{S} 31, \mathrm{~S} 32} / \mathrm{def}-\mathrm{TZVP}{ }^{\mathrm{S} 33}$ level of theory was used for single point calculations on the optimized geometries.

Final Gibbs free energies were obtained by summing the gas phase single point energy $E$, the dispersion correction $E_{D i s p .}$, the ro-vibrational correction $G_{R R H O}$ and the solvation correction $\delta G_{\text {solv }}$ (Eq. S1). 
$G_{\text {tot. }}=E+E_{\text {Disp. }}+G_{R R H O}+\delta G_{\text {solv, corr. }}$ (Equation S1)

\subsection{NBO analysis}

$\mathrm{NBO}$ analyses were carried out with the $\mathrm{NBO}^{\mathrm{S} 34}$ program package implementation in ORCA 4.1 at the geometry optimization level of theory.

\section{$1.4 \mathrm{UV} /$ vis spectra and molecular dynamics simulations}

UV/vis spectra were calculated applying simplified Tamm-Dancoff approximated ${ }^{\mathrm{S} 35}$ time-dependent density functional theory (sTD-DFT) (ORCA 4.1). For the sTD-DFT calculations the BHLYP ${ }^{\mathrm{S} 36}$ hybrid functional was applied with the triple- $\zeta$ def2-TZVPS13 basis set. The RIJCOSX ${ }^{\mathrm{S} 37}$ approximation (GridX6) was applied to accelerate the sTD-DFT calculations. All UV/vis spectra were calculated applying the conductor-like polarizable continuum solvation model ${ }^{\mathrm{S} 38}$ (CPCM) for $n$-hexane.

To obtain averaged UV/vis spectra molecular dynamics (MD) simulations at GFN2-xTB(GBSA(toluene)) level were carried out starting from the corresponding DFT structures. The simulations were carried out for $1000 \mathrm{ps}$ with preceding equilibration for $100 \mathrm{ps}$. A time step of $1 \mathrm{fs}$ was used and the SHAKE ${ }^{\mathrm{S} 39, \mathrm{~S} 40}$ algorithm was applied, constraining all hydrogen containing bonds. From the resulting trajectory 200 snapshots were taken equidistantly and used as structural input for sTDA-xTB calculations. A standard threshold of $7 \mathrm{eV}$ was applied for the sTDA part. The MD averaged absorption spectrum results from a mean over all individual spectra of the snapshots.

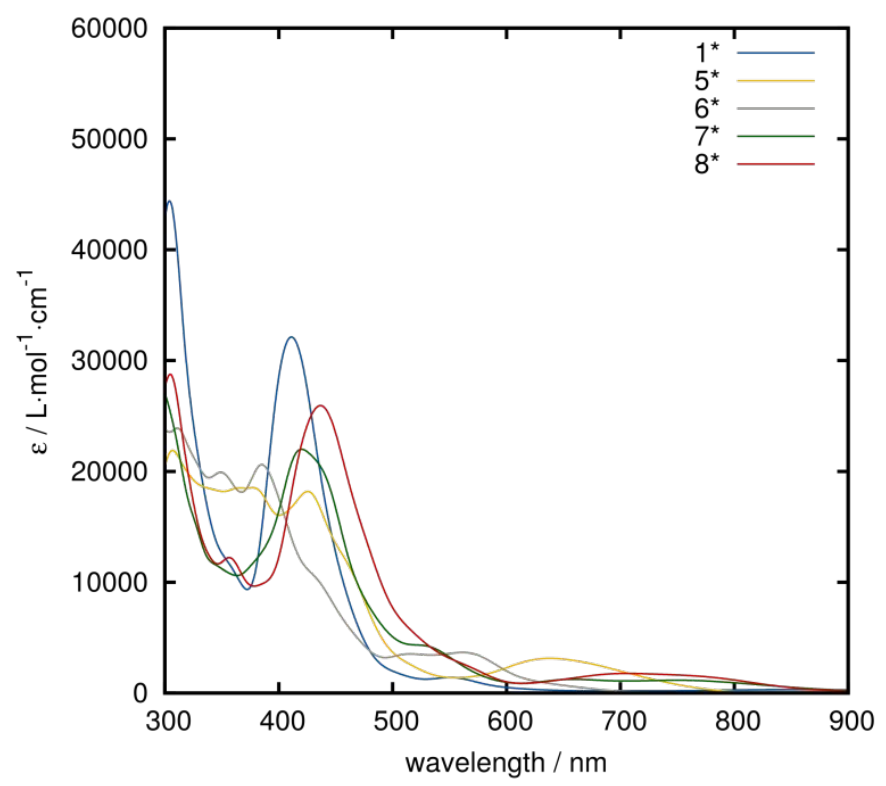

Figure S27. Molecular dynamics averaged UV/vis spectra of all generated structures at sTD$\operatorname{BHLYP}(\mathrm{CPCM}(n$-hexane) level. 


\subsection{Tabulated data}

Table S2. Structure scan data for the model system $\mathrm{Ph}-\mathrm{Pb}-\mathrm{Pb}-\mathrm{Ph}$.

\begin{tabular}{|c|c|c|c|c|c|c|}
\hline $\begin{array}{l}\boldsymbol{9}(\mathrm{C}- \\
\mathrm{Pb}-\mathrm{Pb}- \\
\mathrm{C}) \\
\text { }^{\circ}\end{array}$ & $\begin{array}{l}\varphi(\mathrm{C}- \\
\mathrm{Pb}-\mathrm{Pb}) \\
/^{\circ}\end{array}$ & $\begin{array}{l}\text { E(TPSS- } \\
\text { D3(BJ)- } \\
\text { ATM/def2- } \\
\text { TZVP } \\
\text { / } \\
\text { kcal·mol }^{-1}\end{array}$ & $\begin{array}{l}\mathbf{d}(\mathbf{P b}- \\
\mathbf{P b}) \\
/ \AA\end{array}$ & 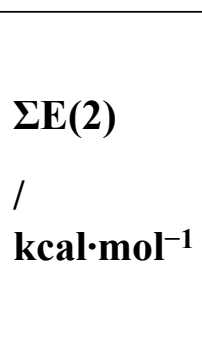 & $\begin{array}{l}\text { NPA/NLMO } \\
\text { BO }\end{array}$ & $\begin{array}{l}\mathbf{E}_{\text {exc. }}(\mathrm{HOMO} \rightarrow \mathrm{LUMO}+\mathbf{1}) \\
/ \mathrm{eV}\end{array}$ \\
\hline 100 & 100 & -849.207 & 3.086 & 0.00 & 1.04 & 1.92 \\
\hline 100 & 105 & -849.205 & 3.072 & 1.23 & 1.07 & 1.87 \\
\hline 100 & 110 & -849.203 & 3.046 & 2.14 & 1.10 & 1.82 \\
\hline 100 & 115 & -849.201 & 3.011 & 3.66 & 1.15 & 1.77 \\
\hline 100 & 120 & -849.198 & 2.972 & 5.99 & 1.21 & 1.72 \\
\hline 100 & 125 & -849.196 & 2.938 & 9.09 & 1.26 & 1.69 \\
\hline 100 & 130 & -849.193 & 2.912 & 12.52 & 1.32 & 1.75 \\
\hline 100 & 90 & -849.210 & 3.062 & 0.00 & 1.02 & 1.99 \\
\hline 100 & 95 & -849.205 & 3.072 & 1.23 & 1.07 & 1.87 \\
\hline 110 & 100 & -849.206 & 3.100 & 0.00 & 1.04 & 2.02 \\
\hline 110 & 105 & -849.204 & 3.077 & 1.25 & 1.07 & 1.97 \\
\hline 110 & 110 & -849.202 & 3.043 & 2.41 & 1.11 & 1.92 \\
\hline 110 & 115 & -849.200 & 2.997 & 4.54 & 1.17 & 1.87 \\
\hline 110 & 120 & -849.198 & 2.949 & 7.92 & 1.24 & 1.83 \\
\hline 110 & 125 & -849.196 & 2.910 & 12.28 & 1.30 & 1.79 \\
\hline 110 & 130 & -849.193 & 2.883 & 16.73 & 1.36 & 1.75 \\
\hline 110 & 90 & -849.210 & 3.070 & 0.00 & 1.03 & 2.10 \\
\hline 110 & 95 & -849.204 & 3.077 & 1.25 & 1.07 & 1.97 \\
\hline 120 & 100 & -849.205 & 3.114 & 0.00 & 1.03 & 2.09 \\
\hline 120 & 105 & -849.204 & 3.090 & 1.14 & 1.06 & 2.06 \\
\hline 120 & 110 & -849.201 & 3.044 & 2.59 & 1.11 & 2.01 \\
\hline
\end{tabular}




\begin{tabular}{|c|c|c|c|c|c|c|}
\hline 120 & 115 & -849.199 & 2.984 & 5.60 & 1.18 & 1.97 \\
\hline 120 & 120 & -849.197 & 2.923 & 10.73 & 1.27 & 1.95 \\
\hline 120 & 125 & -849.195 & 2.881 & 16.79 & 1.35 & 1.92 \\
\hline 120 & 130 & -849.193 & 2.856 & 22.17 & 1.41 & 1.88 \\
\hline 120 & 90 & -849.209 & 3.081 & 0.00 & 1.03 & 2.21 \\
\hline 120 & 95 & -849.204 & 3.090 & 1.14 & 1.06 & 2.06 \\
\hline 130 & 100 & -849.205 & 3.126 & 0.00 & 1.02 & 2.18 \\
\hline 130 & 105 & -849.203 & 3.107 & 0.00 & 1.05 & 2.13 \\
\hline 130 & 110 & -849.200 & 3.052 & 2.59 & 1.10 & 2.09 \\
\hline 130 & 115 & -849.198 & 2.968 & 7.16 & 1.20 & 2.07 \\
\hline 130 & 120 & -849.196 & 2.893 & 15.22 & 1.32 & 2.07 \\
\hline 130 & 125 & -849.195 & 2.852 & 23.01 & 1.40 & 2.06 \\
\hline 130 & 130 & -849.193 & 2.831 & 28.90 & 1.46 & 2.02 \\
\hline 130 & 90 & -849.208 & 3.097 & 0.00 & 1.02 & 2.30 \\
\hline 130 & 95 & -849.203 & 3.107 & 0.00 & 1.05 & 2.13 \\
\hline 140 & 100 & -849.204 & 3.141 & 0.00 & 1.02 & 2.25 \\
\hline 140 & 105 & -849.202 & 3.128 & 0.00 & 1.03 & 2.19 \\
\hline 140 & 110 & -849.199 & 3.074 & 2.23 & 1.09 & 2.15 \\
\hline 140 & 115 & -849.196 & 2.944 & 9.89 & 1.24 & 2.15 \\
\hline 140 & 120 & -849.195 & 2.859 & 22.44 & 1.38 & 2.22 \\
\hline 140 & 125 & -849.195 & 2.825 & 31.26 & 1.46 & 2.21 \\
\hline 140 & 130 & -849.193 & 2.808 & 36.72 & 1.50 & 2.16 \\
\hline 140 & 90 & -849.207 & 3.116 & 0.00 & 1.02 & 2.36 \\
\hline 140 & 95 & -849.202 & 3.128 & 0.00 & 1.03 & 2.19 \\
\hline 150 & 100 & -849.204 & 3.158 & 0.00 & 1.01 & 2.31 \\
\hline 150 & 105 & -849.201 & 3.152 & 0.00 & 1.02 & 2.24 \\
\hline 150 & 110 & -849.197 & 3.115 & 1.38 & 1.06 & 2.19 \\
\hline 150 & 115 & -849.194 & 2.895 & 17.13 & 1.31 & 2.31 \\
\hline
\end{tabular}




\begin{tabular}{|c|c|c|c|c|c|c|}
\hline 150 & 120 & -849.194 & 2.824 & 33.31 & 1.45 & 2.37 \\
\hline 150 & 125 & -849.194 & 2.800 & 41.05 & 1.51 & 2.36 \\
\hline 150 & 130 & -849.193 & 2.790 & 44.99 & 1.55 & 2.31 \\
\hline 150 & 90 & -849.206 & 3.137 & 0.00 & 1.01 & 2.41 \\
\hline 150 & 95 & -849.201 & 3.152 & 0.00 & 1.02 & 2.24 \\
\hline 160 & 100 & -849.203 & 3.172 & 0.00 & 1.00 & 2.35 \\
\hline 160 & 105 & -849.200 & 3.176 & 0.00 & 1.01 & 2.28 \\
\hline 160 & 110 & -849.195 & 3.168 & 0.00 & 1.03 & 1.92 \\
\hline 160 & 115 & -849.193 & 2.829 & 34.79 & 1.43 & 2.50 \\
\hline 160 & 120 & -849.193 & 2.795 & 46.41 & 1.51 & 2.53 \\
\hline 160 & 125 & -849.193 & 2.781 & 51.01 & 1.55 & 2.52 \\
\hline 160 & 130 & -849.193 & 2.776 & 52.67 & 1.58 & 2.46 \\
\hline 160 & 90 & -849.205 & 3.158 & 0.00 & 1.00 & 2.43 \\
\hline 160 & 95 & -849.200 & 3.176 & 0.00 & 1.01 & 2.28 \\
\hline 170 & 100 & -849.203 & 3.183 & 0.00 & 1.00 & 2.37 \\
\hline 170 & 105 & -849.199 & 3.194 & 0.00 & 1.00 & 2.30 \\
\hline 170 & 110 & -849.194 & 3.210 & 0.00 & 1.00 & 2.21 \\
\hline 170 & 115 & -849.191 & 2.789 & 53.97 & 1.52 & 2.21 \\
\hline 170 & 120 & -849.193 & 2.775 & 58.01 & 1.56 & 2.68 \\
\hline 170 & 125 & -849.193 & 2.769 & 58.90 & 1.59 & 2.68 \\
\hline 170 & 130 & -849.193 & 2.767 & 58.33 & 1.60 & 2.62 \\
\hline 170 & 90 & -849.204 & 3.175 & 0.00 & 1.00 & 2.44 \\
\hline 170 & 95 & -849.199 & 3.194 & 0.00 & 1.00 & 2.30 \\
\hline 180 & 100 & -849.203 & 3.186 & 0.00 & 1.00 & 2.38 \\
\hline 180 & 105 & -849.199 & 3.202 & 0.00 & 1.00 & 2.30 \\
\hline 180 & 110 & -849.188 & 2.783 & 63.17 & 1.52 & 2.68 \\
\hline 180 & 115 & -849.191 & 2.774 & 63.58 & 1.55 & 2.73 \\
\hline 180 & 120 & -849.192 & 2.768 & 63.20 & 1.58 & 2.76 \\
\hline
\end{tabular}




\begin{tabular}{lllllll}
180 & 125 & -849.193 & 2.765 & 62.12 & 1.60 & 2.79 \\
180 & 130 & -849.193 & 2.765 & 60.47 & 1.61 & 2.76 \\
180 & 90 & -849.203 & 3.185 & 0.00 & 1.00 & 2.43 \\
180 & 95 & -849.199 & 3.202 & 0.00 & 1.00 & 2.30 \\
90 & 90 & -849.211 & 3.057 & 0.00 & 1.03 & 1.88 \\
90 & 100 & -849.207 & 3.081 & 0.00 & 1.05 & 1.82 \\
90 & 105 & -849.206 & 3.071 & 1.12 & 1.07 & 1.78 \\
90 & 110 & -849.203 & 3.051 & 1.83 & 1.10 & 1.74 \\
90 & 115 & -849.201 & 3.025 & 2.94 & 1.13 & 1.74 \\
90 & 120 & -849.198 & 2.994 & 4.56 & 1.18 & 1.75 \\
90 & 125 & -849.195 & 2.966 & 6.69 & 1.23 & 1.78 \\
90 & 130 & -849.192 & 2.942 & 9.23 & 1.27 & 1.83 \\
90 & 95 & -849.206 & 3.071 & 1.12 & 1.07 & 1.78 \\
\hline
\end{tabular}


Table S3. Absolute contributions to $\mathrm{G}_{\mathrm{tot}}$ in $\mathrm{kcal} \cdot \mathrm{mol}^{-1}$. All calculations were conducted applying the $\mathrm{C}_{1}$ point group. "Frag" denotes the PbR fragment in the doublet ground state.

\begin{tabular}{|c|c|c|c|c|c|c|c|c|c|c|}
\hline & $\begin{array}{l}\text { TPSS- } \\
\text { D3(BJ)- } \\
\text { ATM/def2- } \\
\text { TZVP } \\
\text { / a.u. }\end{array}$ & $\begin{array}{l}\text { PBE0/def2- } \\
\text { TZVPP } \\
\text { / a.u. }\end{array}$ & $\begin{array}{l}\text { PBE0/def2- } \\
\text { TZVPP } \\
\text { / kcal mol }\end{array}$ & $\begin{array}{l}\text { E }_{\text {D3, ATM }} \\
(\text { PBE0) } \\
/ \text { kcal }^{-1}\end{array}$ & $\begin{array}{l}\mathbf{E}_{\mathrm{D} 4, \mathrm{ATM}} \\
\text { (PBE0) } \\
/ \text { kcal } \\
\mathrm{mol}^{-}\end{array}$ & $\begin{array}{ll}\text { B3LYP/def2-B3LYP/def2- } \\
\text { TZVPP } & \text { TZVPP } \\
\text { / a.u. } & / \mathrm{kcal} \mathrm{mol}^{-1}\end{array}$ & $\begin{array}{l}\text { E }_{\mathrm{D}, \text { ATM }} \\
(\mathrm{B3LYP}) \\
/ \text { kcal } \\
\mathrm{mol}^{-1}\end{array}$ & $\begin{array}{l}\mathbf{E}_{\mathrm{D4}, \mathrm{ATM}} \\
(\mathrm{B} 3 \mathrm{LYP}) \\
/ \mathrm{kcal} \\
\mathrm{mol}^{-}\end{array}$ & $\begin{array}{l}\mathbf{G}_{\text {RRHO }} \\
\left(25.0^{\circ} \mathrm{C}\right) \\
/ \mathrm{kcal}^{-1} \\
\text { mol }^{-1}\end{array}$ & $\begin{array}{l}\delta G_{\text {solv., }} \\
\text { corr. } \\
(n- \\
\text { hexane, } \\
25.0^{\circ} \mathrm{C} \text { ) } \\
/ \text { kcal }^{\text {mol }^{-1}}\end{array}$ \\
\hline 1 & - 3190.236741 & - & $\overline{1999307.18}$ & -179.39 & -179.66 & $-3187.563546-2000226.32$ & -320.25 & -307.07 & 864.84 & -32.93 \\
\hline $\mathbf{1}_{\text {frag }}$ & $\begin{array}{l}- \\
1595.082561\end{array}$ & $\begin{array}{l}- \\
1593.037289\end{array}$ & -999645.99 & -75.51 & -76.43 & $-1593.779013-1000111.43$ & -138.44 & -134.09 & 421.47 & -19.09 \\
\hline 5 & $\begin{array}{l}- \\
3662.300438\end{array}$ & - 3657.429249 & $\begin{array}{l}- \\
2295071.51\end{array}$ & -216.18 & -216.17 & $-3659.128946-2296138.08$ & -384.29 & -368.14 & 1063.90 & -37.32 \\
\hline $5_{\text {frag }}$ & $\begin{array}{l}- \\
1831.116954\end{array}$ & - & 1147531.36 & -93.84 & -94.78 & $-1829.567212-1148070.76$ & -170.41 & -164.82 & 520.80 & -21.47 \\
\hline 6 & $\begin{array}{l}- \\
3662.182576\end{array}$ & 3657.284477 & $\begin{array}{l}- \\
2294980.66\end{array}$ & -228.36 & -228.35 & $-3658.963293-2296034.13$ & -406.80 & -389.96 & 1069.93 & -34.73 \\
\hline $6_{\text {frag }}$ & - 1831.053437 & - & - & -98.11 & -99.12 & $-1829.482243-1148017.44$ & -178.92 & -173.24 & 524.62 & -20.71 \\
\hline
\end{tabular}




\begin{tabular}{|c|c|c|c|c|c|c|c|}
\hline 7 & $\begin{array}{c}- \\
2718.1699412714 .7492881703530 .90\end{array}$ & -149.16 & $-2715.971674-1704297.96$ & -266.86 & -256.46 & 668.23 & -28.58 \\
\hline $7_{\text {frag }}$ & $-{ }^{-}-1359.0494321357 .359021^{-851755.65}-62.57$ & -63.64 & $-1357.978125-852144.14$ & -115.18 & -111.97 & 323.55 & -15.84 \\
\hline 8 & 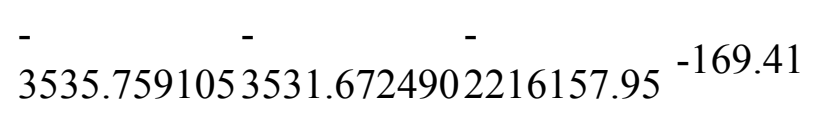 & -169.85 & $-3533.187944-2217108.91$ & -304.11 & -291.41 & 781.29 & -30.26 \\
\hline $8_{\text {frag }}$ & $-{ }^{-} \overline{1}_{1767.8431281765 .8205191108069 .11^{-72.62}}$ & -73.52 & $-1766.586573-1108549.81$ & -133.14 & -128.79 & 380.06 & -17.57 \\
\hline $1 *$ & $\begin{array}{l}- \\
3190.2362333186 .0972381999306 .20^{-177.07}\end{array}$ & -177.47 & $-3187.559052-2000223.50$ & -318.10 & -305.03 & 864.95 & -32.89 \\
\hline $5 *$ & $\begin{array}{lcc}- & - & - \\
3662.2893173657 .4184582295064 .73 & & \end{array}$ & -216.76 & $-3659.115764-2296129.81$ & -385.02 & -369.01 & 1066.59 & -37.16 \\
\hline 6* & $\begin{array}{lcc}- & - & - \\
3662.1607173657 .2697682294971 .43 & -223.97\end{array}$ & -223.56 & $-3658.951788-2296026.91$ & -399.88 & -382.73 & 1069.44 & -35.63 \\
\hline $7 *$ & $\begin{array}{l}- \\
2718.1651762714 .7395541703524 .79\end{array}$ & -148.66 & $-2715.957071-1704288.79$ & -266.99 & -256.67 & 667.44 & -28.17 \\
\hline 8* & 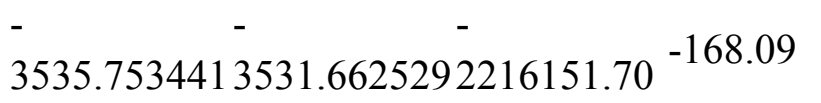 & -168.79 & $-3533.173468-2217099.83$ & -303.50 & -290.92 & 781.89 & -29.67 \\
\hline
\end{tabular}


$\Delta E_{\text {Disp. }}=E_{\text {Disp., complex }}-\left(E_{\text {Disp., fragment 1 }}+E_{\text {Disp., fragment 2 }}\right) \quad$ (Equation S2)

Table S4. $\Delta \mathrm{E}_{\text {Disp. }}$ and absolute dispersion corrections for the full complex and its unrelaxed fragments in $\mathrm{kcal} \cdot \mathrm{mol}^{-1}$.

\begin{tabular}{|c|c|c|c|c|c|}
\hline & & PBEO & & B3LYP & \\
\hline & & D3(BJ)-ATM & $\begin{array}{l}\text { D4(EEQ)- } \\
\text { ATM }\end{array}$ & D3(BJ)-ATM & $\begin{array}{l}\text { D4(EEQ)- } \\
\text { ATM }\end{array}$ \\
\hline 1 & $\mathrm{E}_{\text {Disp., complex }}$ & -179.39 & -179.66 & -320.25 & -307.07 \\
\hline & $\mathrm{E}_{\text {Disp., fragment } 1}$ & -74.22 & -74.86 & -136.00 & -131.34 \\
\hline & $\mathrm{E}_{\text {Disp., fragment } 2}$ & -74.22 & -74.87 & -136.01 & -131.35 \\
\hline & $\Delta \mathrm{E}_{\text {Disp. }}$ & -30.94 & -29.93 & -48.24 & -44.39 \\
\hline 5 & $\mathrm{E}_{\text {Disp., complex }}$ & -216.18 & -216.17 & -384.29 & -368.14 \\
\hline & $\mathrm{E}_{\text {Disp., fragment } 1}$ & -93.77 & -94.43 & -170.25 & -164.17 \\
\hline & $\mathrm{E}_{\text {Disp., fragment } 2}$ & -93.61 & -94.29 & -169.94 & -163.91 \\
\hline & $\Delta \mathrm{E}_{\text {Disp. }}$ & -28.79 & -27.45 & -44.10 & -40.07 \\
\hline 6 & $\mathrm{E}_{\text {Disp., complex }}$ & -228.36 & -228.35 & -406.80 & -389.96 \\
\hline & $\mathrm{E}_{\text {Disp., fragment } 1}$ & -97.19 & -98.11 & -177.19 & -171.42 \\
\hline & $\mathrm{E}_{\text {Disp., fragment } 2}$ & -98.07 & -98.56 & -178.64 & -172.10 \\
\hline & $\Delta \mathrm{E}_{\text {Disp. }}$ & -33.10 & -31.69 & -50.97 & -46.44 \\
\hline 7 & $\mathrm{E}_{\text {Disp., complex }}$ & -148.39 & -149.16 & -266.86 & -256.46 \\
\hline & $\mathrm{E}_{\text {Disp., fragment } 1}$ & -61.73 & -62.49 & -113.44 & -109.86 \\
\hline & $\mathrm{E}_{\text {Disp., fragment } 2}$ & -61.73 & -62.50 & -113.44 & -109.86 \\
\hline & $\Delta \mathrm{E}_{\text {Disp. }}$ & -24.94 & -24.17 & -39.97 & -36.74 \\
\hline 8 & $\mathrm{E}_{\text {Disp., complex }}$ & -169.41 & -169.85 & -304.11 & -291.41 \\
\hline & $\mathrm{E}_{\text {Disp., fragment } 1}$ & -72.18 & -72.76 & -132.02 & -127.26 \\
\hline & $\mathrm{E}_{\text {Disp., fragment } 2}$ & -72.19 & -72.78 & -132.05 & -127.28 \\
\hline & $\Delta \mathrm{E}_{\text {Disp. }}$ & -25.04 & -24.31 & -40.04 & -36.87 \\
\hline
\end{tabular}




\begin{tabular}{|c|c|c|c|c|c|}
\hline \multirow[t]{4}{*}{$1 *$} & $\mathrm{E}_{\text {Disp., complex }}$ & -177.07 & -177.07 & -318.10 & -305.03 \\
\hline & $\mathrm{E}_{\text {Disp., fragment } 1}$ & -75.13 & -75.86 & -138.03 & -133.29 \\
\hline & $\mathrm{E}_{\text {Disp., fragment } 2}$ & -75.17 & -75.89 & -138.09 & -133.33 \\
\hline & $\Delta \mathrm{E}_{\text {Disp. }}$ & -26.76 & -25.32 & -41.99 & -38.41 \\
\hline \multirow[t]{4}{*}{$5 *$} & $\mathrm{E}_{\text {Disp., complex }}$ & -216.54 & -216.76 & -385.02 & -369.01 \\
\hline & $\mathrm{E}_{\text {Disp., fragment } 1}$ & -93.87 & -94.56 & -170.25 & -164.24 \\
\hline & $\mathrm{E}_{\text {Disp., fragment } 2}$ & -93.58 & -94.42 & -169.98 & -164.22 \\
\hline & $\Delta \mathrm{E}_{\text {Disp. }}$ & -29.09 & -27.78 & -44.79 & -40.54 \\
\hline \multirow[t]{4}{*}{$6 *$} & $\mathrm{E}_{\text {Disp., complex }}$ & -223.97 & -223.56 & -399.88 & -382.73 \\
\hline & $\mathrm{E}_{\text {Disp., fragment } 1}$ & -97.64 & -98.12 & -178.02 & -171.51 \\
\hline & $\mathrm{E}_{\text {Disp., fragment } 2}$ & -97.64 & -98.12 & -178.03 & -171.51 \\
\hline & $\Delta \mathrm{E}_{\text {Disp. }}$ & -28.69 & -27.32 & -43.83 & -39.72 \\
\hline \multirow[t]{4}{*}{$7 *$} & $\mathrm{E}_{\text {Disp., complex }}$ & -147.64 & -148.66 & -266.99 & -256.67 \\
\hline & $\mathrm{E}_{\text {Disp., fragment } 1}$ & -63.25 & -64.24 & -116.57 & -113.09 \\
\hline & $\mathrm{E}_{\text {Disp., fragment } 2}$ & -63.24 & -64.23 & -116.55 & -113.07 \\
\hline & $\Delta \mathrm{E}_{\text {Disp. }}$ & -21.15 & -20.19 & -33.87 & -30.52 \\
\hline \multirow[t]{4}{*}{ 8* } & $\mathrm{E}_{\text {Disp., complex }}$ & -168.09 & -168.79 & -303.50 & -290.92 \\
\hline & $\mathrm{E}_{\text {Disp., fragment } 1}$ & -73.41 & -74.22 & -134.76 & -130.11 \\
\hline & $\mathrm{E}_{\text {Disp., fragment } 2}$ & -73.38 & -74.19 & -134.70 & -130.05 \\
\hline & $\Delta \mathrm{E}_{\text {Disp. }}$ & -21.29 & -20.38 & -34.05 & -30.76 \\
\hline
\end{tabular}




\section{References}

(S1) Stanciu, C.; Richards, A. F.; Fettinger, J. C.; Brynda, M.; Power, P. P. Synthesis and Characterization of New, Modified Terphenyl Ligands: Increasing the Rotational Barrier for Flanking Rings. J. Organomet. Chem. 2006, 691, 2540-2545. https://doi.org/10.1016/J.JORGANCHEM.2006.01.046.

(S2) Hino, S.; Olmstead, M. M.; Phillips, A. D.; Wright, R. J.; Power, P. P. Terphenyl Ligand Stabilized Lead(II) Derivatives: Steric Effects and Lead-Lead Bonding in Diplumbenes. Inorg. Chem. 2004, 43, 7346-7352. https://doi.org/10.1021/ic049174y.

(S3) Pettersen, E. F.; Goddard, T. D.; Huang, C. C.; Couch, G. S.; Greenblatt, D. M.; Meng, E. C.; Ferrin, T. E. UCSF Chimera - A Visualization System for Exploratory Research and Analysis. $J$. Comput. Chem. 2004, 25, 1605-1612. https://doi.org/10.1002/jcc.20084.

(S4) Furche, F.; Ahlrichs, R.; Hättig, C.; Klopper, W.; Sierka, M.; Weigend, F. Turbomole. WIREs Comput Mol Sci 2014, 4, 91-100.

(S5) TURBOMOLE V7.0.2 2015, a Development of University of Karlsruhe and Forschungszentrum Karlsruhe GmbH, 1989-2007, TURBOMOLE GmbH, since 2007; Available from Http://Www.Turbomole.Com.

(S6) Neese, F. The ORCA Program System. Wiley Interdiscip. Rev. Comput. Mol. Sci. 2012, 2, 73-78. https://doi.org/10.1002/wcms.81.

(S7) Neese, F. ORCA: An Ab Initio, Density Functional and Semiempirical Program Package, V. 4.1.0; MPI Für Chemische Energiekonversion: Mülheim a. d. Ruhr, Germany, 2019.

(S8) Grimme, S. XTB, V. 6.1; Mulliken Center for Theoretical Chemistry, University of Bonn. 2019.

(S9) Furche, F.; Ahlrichs, R.; Hättig, C.; Klopper, W.; Sierka, M.; Weigend, F. Turbomole. WIREs Comput. Mol. Sci. 2014, 4, 91-100. https://doi.org/10.1002/wcms.1162.

(S10) TURBOMOLE V7.2 2017, a Development of University of Karlsruhe and Forschungszentrum Karlsruhe GmbH, 1989-2007, TURBOMOLE GmbH, since 2007; Available from Http://Www.Turbomole.Com.

(S11) Bannwarth, C.; Ehlert, S.; Grimme, S. GFN2-XTB-An Accurate and Broadly Parametrized SelfConsistent Tight-Binding Quantum Chemical Method with Multipole Electrostatics and DensityDependent Dispersion Contributions. J. Chem. Theory Comput. 2019, 15, 1652-1671. https://doi.org/10.1021/acs.jctc.8b01176.

(S12) Tao, J.; Perdew, J. P.; Staroverov, V. N.; Scuseria, G. E. Climbing the Density Functional Ladder: Nonempirical Meta-Generalized Gradient Approximation Designed for Molecules and Solids. Phys. Rev. Lett. 2003, 91, 146401. https://doi.org/10.1103/PhysRevLett.91.146401.

(S13) Weigend, F.; Ahlrichs, R. Balanced Basis Sets of Split Valence, Triple Zeta Valence and Quadruple Zeta Valence Quality for H to Rn: Design and Assessment of Accuracy. Phys. Chem. Chem. Phys. 2005, 7, 3297. https://doi.org/10.1039/b508541a.

(S14) Metz, B.; Stoll, H.; Dolg, M. Small-Core Multiconfiguration-Dirac-Hartree-Fock-Adjusted Pseudopotentials for Post-d Main Group Elements: Application to $\mathrm{PbH}$ and $\mathrm{PbO}$. J. Chem. Phys. 
2000, 113, 2563-2569. https://doi.org/10.1063/1.1305880.

(S15) Eichkorn, K.; Treutler, O.; Öhm, H.; Häser, M.; Ahlrichs, R. Auxiliary Basis Sets to Approximate Coulomb Potentials. Chem. Phys. Lett. 1995, 240, 283-289. https://doi.org/10.1016/00092614(95)00621-A.

(S16) Weigend, F. Accurate Coulomb-Fitting Basis Sets for H to Rn. Phys. Chem. Chem. Phys. 2006, 8, 1057. https://doi.org/10.1039/b515623h.

(S17) Grimme, S.; Antony, J.; Ehrlich, S.; Krieg, H. A Consistent and Accurate Ab Initio Parametrization of Density Functional Dispersion Correction (DFT-D) for the 94 Elements H-Pu. J. Chem. Phys. 2010, 132, 154104. https://doi.org/10.1063/1.3382344.

(S18) Caldeweyher, E.; Ehlert, S.; Hansen, A.; Neugebauer, H.; Spicher, S.; Bannwarth, C.; Grimme, S. A Generally Applicable Atomic-Charge Dependent London Dispersion Correction. J. Chem. Phys. 2019, 150, 154122. https://doi.org/10.1063/1.5090222.

(S19) Caldeweyher, E.; Bannwarth, C.; Grimme, S. Extension of the D3 Dispersion Coefficient Model. J. Chem. Phys. 2017, 147, 034112. https://doi.org/10.1063/1.4993215.

(S20) Grimme, S.; Ehrlich, S.; Goerigk, L. Effect of the Damping Function in Dispersion Corrected Density Functional Theory. J. Comput. Chem. 2011, 32, 1456-1465. https://doi.org/10.1002/jcc.21759.

(S21) Becke, A. D.; Johnson, E. R. A Density-Functional Model of the Dispersion Interaction. J. Chem. Phys. 2005, 123, 154101. https://doi.org/10.1063/1.2065267.

(S22) Axilrod, B. M.; Teller, E. Interaction of the van Der Waals Type between Three Atoms. J. Chem. Phys. 1943, 11, 299-300. https://doi.org/10.1063/1.1723844.

(S23) Muto, Y. Force between Nonpolar Molecules. Proc. Phys. Math. Soc. Jpn. 1943, 17, 629-631.

(S24) Grimme, S.; Hansen, A.; Brandenburg, J. G.; Bannwarth, C. Dispersion-Corrected Mean-Field Electronic Structure Methods. Chem. Rev. 2016, 116, 5105-5154. https://doi.org/10.1021/acs.chemrev.5b00533.

(S25) Grimme, S. Supramolecular Binding Thermodynamics by Dispersion-Corrected Density Functional Theory. Chem. - A Eur. J. 2012, 18, 9955-9964. https://doi.org/10.1002/chem.201200497.

(S26) Adamo, C.; Barone, V. Toward Reliable Density Functional Methods without Adjustable Parameters: The PBE0 Model. J. Chem. Phys. 1999, 110, 6158-6170. https://doi.org/10.1063/1.478522.

(S27) Becke, A. D. Density-Functional Thermochemistry. III. The Role of Exact Exchange. J. Chem. Phys. 1993, 98, 5648-5652. https://doi.org/10.1063/1.464913.

(S28) Klamt, A. Conductor-like Screening Model for Real Solvents: A New Approach to the Quantitative Calculation of Solvation Phenomena. J. Phys. Chem. 1995, 99, 2224-2235. https://doi.org/10.1021/j100007a062.

(S29) Eckert, F.; Klamt, A. Fast Solvent Screening via Quantum Chemistry: COSMO-RS Approach. AIChE J. 2002, 48, 369-385. https://doi.org/10.1002/aic.690480220. 
(S30) Klamt, A.; Eckert, F.; Pohler, L. COSMOtherm. COSMOlogic GmbH \& Co. KG: Leverkusen, Germany 2013.

(S31) Becke, A. D. Density-Functional Exchange-Energy Approximation with Correct Asymptotic Behavior. Phys. Rev. A 1988, 38, 3098-3100. https://doi.org/10.1103/PhysRevA.38.3098.

(S32) Perdew, J. P. Density-Functional Approximation for the Correlation Energy of the Inhomogeneous Electron Gas. Phys. Rev. B 1986, 33, 8822-8824. https://doi.org/10.1103/PhysRevB.33.8822.

(S33) Schäfer, A.; Huber, C.; Ahlrichs, R.; Schafer, A.; Huber, C.; Ahlrichs, R. Fully Optimized Contracted Gaussian Basis Sets of Triple Zeta Valence Quality for Atoms Li to Kr Fully Optimized Contracted Gaussian Basis Sets of Triple Zeta Valence Quality for Atoms Li to Kr. $J$. Chem. Phys. 1994, 100, 5829-5835. https://doi.org/10.1063/1.467146.

(S34) Glendening, E. D.; Badenhoop, J. K.; Reed, A. E.; Carpenter, J. E.; Bohmann, J. A.; Morales, C. M.; Landis, C. R.; Weinhold, F. NBO 6.0. Theoretical Chemistry Institute, University of Wisconsin: Madison 2013.

(S35) Grimme, S. A Simplified Tamm-Dancoff Density Functional Approach for the Electronic Excitation Spectra of Very Large Molecules. J. Chem. Phys. 2013, 138, 244104. https://doi.org/10.1063/1.4811331.

(S36) Becke, A. D. A New Mixing of Hartree-Fock and Local Density-Functional Theories. J. Chem. Phys. 1993, 98, 1372-1377. https://doi.org/10.1063/1.464304.

(S37) Neese, F.; Wennmohs, F.; Hansen, A.; Becker, U. Efficient, Approximate and Parallel HartreeFock and Hybrid DFT Calculations. A "chain-of-Spheres" Algorithm for the Hartree-Fock Exchange. Chem. Phys. 2009, 356, 98-109. https://doi.org/10.1016/j.chemphys.2008.10.036.

(S38) Barone, V.; Cossi, M. Quantum Calculation of Molecular Energies and Energy Gradients in Solution by a Conductor Solvent Model. J. Phys. Chem. A 1998, 102, 1995-2001. https://doi.org/10.1021/jp9716997.

(S39) Ryckaert, J. P.; Ciccotti, G.; Berendsen, H. J. C. Numerical Integration of the Cartesian Equations of Motion of a System with Constraints: Molecular Dynamics of n-Alkanes. J. Comput. Phys. 1977, 23, 327-341. https://doi.org/10.1016/0021-9991(77)90098-5.

(S40) Van Gunsteren, W. F.; Berendsen, H. J. C. Algorithms for Macromolecular Dynamics and Constraintdynamics. Mol. Phys. 1977, 34, 1311-1327. https://doi.org/10.1080/00268977700102571. 